HIAS-E-25

\title{
Perverse Consequences of Well-Intentioned Regulation: Evidence from India's Child Labor Ban
}

\author{
Prachant Bharadwaj \\ Department of Economics, University of California, San Diego \\ Leah K. Lakdawala \\ Department of Economics, Michigan State University \\ Nicholas Li \\ Department of Economics, University of Toronto
}

April 2, 2016

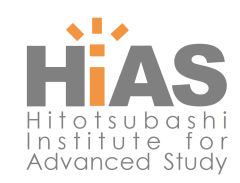

Hitotsubashi Institute for Advanced Study, Hitotsubashi University

2-1, Naka, Kunitachi, Tokyo 186-8601, Japan

tel:+81 425808604 http://hias.ad.hit-u.ac.jp/

HIAS discussion papers can be downloaded without charge from:

http://hdl.handle.net/10086/27202

https://ideas.repec.org/s/hit/hiasdp.html

All rights reserved. 


\title{
PERVERSE CONSEQUENCES OF WELL-INTENTIONED REGULATION: EVIDENCE FROM INDIA'S CHILD LABOR BAN
}

\author{
PRASHANT BHARADWAJ ${ }^{\dagger}$, LEAH K. LAKDAWALA ${ }^{\dagger \dagger}$ \& NICHOLAS LI ${ }^{\dagger \dagger \dagger}$
}

\begin{abstract}
While bans against child labor are a ubiquitous policy tool, there is very little empirical evidence on their effectiveness. In this paper, we examine the consequences of India's landmark legislation against child labor, the Child Labor (Prohibition and Regulation) Act of 1986. Using data from employment surveys conducted before and after the ban, and using age restrictions that determined whom the ban applied to, we show that the relative probability of child employment increases and child wages (relative to adult wages) decrease after the ban. Our main specification relies on comparing changes in work probabilities over time for children of the same age but with siblings who are rendered either eligible or ineligible for legal work when the ban is implemented. The increases in the probability of economic activity are largest for children in areas where (i) the industries targeted by the ban play a larger role in local labor markets and (ii) the probability of employer inspections are higher. These results are consistent with a theoretical model building on the seminal work of Basu and Van (1998) and Basu (2005), where families use child labor to reach subsistence constraints and where child wages decrease in response to bans, leading poor families to utilize more child labor. We also examine the effects of the ban at the household level. Using linked consumption and expenditure data, we find that along the margins of assets and share of staple goods in calorie consumption, households are worse off after the ban.
\end{abstract}

JEL Codes: I38, J22, J82, O12

\footnotetext{
$\dagger$ Department of Economics, University of CALifornia, San Diego ${ }^{\dagger \dagger}$ Department of Economics, Michigan State University ${ }^{\dagger \dagger}$ DEPARTMENT OF ECONOMICS, UNIVERSiTy OF TORONTO E-mail address: prbharadwaj@ucsd.edu, lkl@msu.edu, nick.li@utoronto.ca. Date: April 2nd, 2016.

Thanks to Chris Ahlin, Kate Antonovics, Jeff Clemens, Julie Cullen, Gordon Dahl, Rahul Deb, Eric Edmonds, James Fenske, Gordon Hanson, Anjini Kochar, Craig McIntosh, Arijit Mukherjee, Karthik Muralidharan, Paul Niehaus, Mallesh Pai and Maher Said for insightful discussions on the topic. Zachary Breig provided excellent research assistance. Bharadwaj thanks the Hitotsubashi Institute for Advanced Study, Hitotsubashi University. The online Appendix for this paper can be found at http://prbharadwaj.wordpress.com/papers/.
} 


\section{INTRODUCTION}

Legal interventions are a common tool used by societies seeking to bring about equality and justice. Bans against child marriage, racial segregation in schooling, and discriminatory hiring practices are prime examples of legal action intended to improve overall welfare and create equality of opportunity. While legal interventions have undoubtedly been effective in many situations, the possibility that well-intentioned laws can have perverse or self-defeating consequences is a central concern in the economic analysis of laws and regulations (Sunstein 1994). This possibility is crucial when evaluating the consequences of legal action taken against a controversial yet pervasive aspect of developing societies: child labor.

Despite facing near universal opposition for decades, child labor is endemic. According to a recent report by the International Labor Organization, there are nearly 168 million child laborers, of whom 85 million work under hazardous conditions (International Labour Organization (2013)). While many policy options exist to address this, laws banning or regulating child labor remain the predominant response. ${ }^{1}$ However, the effect of these laws on child labor and household welfare is theoretically ambiguous (see Basu and Van (1998) and Baland and Robinson (2000)). On the one hand, when properly enforced, bans increase the cost to employers of hiring children thereby deterring their use. On the other hand, if poor families use child work in order to reach subsistence and employers pass on expected fines for hiring child labor through to child wages, the resulting fall in child wages may actually lead families to supply more child labor (Basu (1999), Basu (2005)). The latter result especially rings true when states lack the capacity to enforce child labor regulation - a likely scenario in developing countries. Given the theoretical ambiguities in academic work, what does rigorous empirical work have to say about the impacts of such bans? In a comprehensive review, Edmonds (2007) concludes, “... despite all this policy discussion, there does not appear to be any study of the effectiveness of restrictions on work that would meet current standards of evidence." (pg. 66)

\footnotetext{
${ }^{1}$ Bans and regulations against child labor are common all over the world. In a detailed report published by the US Department of Labor's Bureau of International Labor Affairs, such regulations are found in countries like Egypt, Kenya, Nicaragua, Mexico and Thailand (US Department of Labor 1998).
} 
This paper sets out to fill this critical gap in the literature by examining the impact of India's flagship legislation against child labor, the Child Labor (Prohibition and Regulation) Act of 1986, which banned employment of children under the age of 14 in various occupations and industries. ${ }^{2}$ Most recent articles in the press cite this law as the starting point for legal action against child labor in India. Our results are important for understanding the impacts of such bans in settings where people live at the margin of subsistence and where legal enforcement is weak. Given the dearth of rigorous empirical evaluations of child labor bans in such settings, our paper bridges a fundamental gap in this literature. ${ }^{3}$

In Basu's (2005) one sector model, an imperfectly enforced ban lowers child wages, which forces families reliant on child labor income for subsistence to further increase levels of child labor. A two sector extension of this model with the ban applying to only one sector (as was the case with the 1986 law) illustrates that the state of the labor market is important for determining the effects of a ban in one sector. Specifically when there are no labor market frictions that prevent free movement of labor from one sector to another, the ban has no impact on overall levels of child labor but simply reallocates it across sectors as in Edmonds and Shrestha (2012a). However when movement between sectors is limited, the main insight of the Basu (2005) model is preserved. In this case, a ban in one sector may increase child labor in either or both sectors.

We test the predictions of this theory using several difference in differences models and detailed data on employment from the multiple rounds of the National Sample Survey in India. We classify data before 1986 as the "pre-ban" period and data gathered after 1986 as the "post-ban"

\footnotetext{
${ }^{2}$ While there is a wealth of empirical and theoretical work examining the determinants (see excellent reviews by Basu (1999), Edmonds et al. (2010), Edmonds (2007)) and consequences (see for example Beegle et al. (2009)) of child labor there is little empirical evidence on the effectiveness of child labor bans in developing countries. Nonetheless, the theoretical research in this area is quite rich (see for example Baland and Robinson (2000), Basu and Van (1998), and Doepke and Zilibotti (2005)). There have been numerous evaluations of related policies like cash transfers that are directly intended to affect child labor (see Skoufias et al. (2001) among many others) and policies like trade liberalization that affect child labor indirectly (see Edmonds and Pavcnik (2005b)).

${ }^{3}$ A number of studies focus on the impact of child labor legislation in the U.S. (Moehling (1999), Lleras-Muney (2002), Manacorda (2006), Bugni (2012)) but to our knowledge the only other paper to consider the effect of such legislation on child work outcomes in the developing country context is Edmonds and Shrestha (2012a). Edmonds and Shrestha (2012a) use country-level variation in minimum age restrictions for work but find no evidence of a discontinuity in the likelihood at work at mandated minimum ages. They conclude that such restrictions on paper appear to have no impact on the incidence of child employment, suggesting that the enforcement of such restrictions is weak at best. Similarly, Boockmann (2010) finds little evidence that ILO minimum age conventions increase school attendance. Piza (2014) uses week of birth in an regression discontinuity design and finds that in terms of adult labor market outcomes, whites benefit while non-whites are harmed by a ban enforced during their childhood.
} 
period. To estimate the overall impact of the ban on child time allocation, we compare the changes in employment of children below the age of 14 to the changes of those over 14, since the 1986 Act applied only to those under age 14 . However, given that this basic strategy may be influenced by pre-existing differences in the pre-ban levels or trajectories of work for children over and under age 14, our main empirical approach relies on two alternate strategies. The first uses predictions from the theoretical model and sibling work eligibility to assess the impact of the ban. Specifically, the theoretical model predicts that the ban will have an income effect on families with working children; as wages fall for those targeted by the ban (under the age of 14), incomes of their families fall and thus their younger siblings are forced into the labor market. Therefore our main estimating equation is a difference-in-difference specification that compares the change in labor supply for children of the same age but whose siblings are under or over the legal working age. ${ }^{4}$ This siblingbased strategy directly addresses many of the issues related the simple difference-in-difference approach based on own age - such as differences in the pre-ban levels or trajectories of child labor for older and younger children - as it restricts comparisons to children of the same age. The second approach exploits geographical heterogeneity in the predicted effects of the ban. In particular, we use two measures of geographical heterogeneity in a triple-difference strategy: (i) the importance of industries targeted by the ban in local labor markets, calculated as the state-wide proportion of households who are principally engaged in work in banned industries dring the pre-ban period and (ii) the probability of employer inspection using data on inspections for child labor infractions and the pre-ban incidence of child employment in banned industries at the state level. As discussed in detail in Sections 5.2 and 5.3, the sibling-based and geographical heterogeneity approaches are not subject to the same econometric concerns as the more straightforward difference-in-difference specification based (solely) on own age.

\footnotetext{
${ }^{4}$ This strategy is similar to that used in Manacorda (2006), but differs in that we use siblings to identify which children were affected by the ban through the pathway of child wages and household income rather than using age eligibility of siblings to study the impact of one sibling's labor supply on another. As described in greater detail in Section 5.2, we use sibling age to identify children whose siblings are both likely to be working (as in Manacorda (2006)) and likely to suffer a wage reduction due to the ban.
} 
Our simple difference-in-difference estimates show that the probability a child under 14 is economically active relative to a child over 14 rose by 2.6 percentage points after the ban. ${ }^{5}$ It is worth noting that overall the period under study was characterized by rising incomes and a steady decline in the probability of working for all children under 18; thus our findings imply that employment of children under 14 did not decrease by as much as it would have had the 1986 Act not been implemented. Given the potential issues with the simple difference-in-difference strategy outlined above, we regard the results from this method as largely descriptive. Using the sibling-based difference-in-difference approach more closely tied to the theoretical model and less subject to the criticisms of the simple strategy, our results show that a child between the ages of 10-13 with a sibling below the age of 14 significantly increases her likelihood of economic activity by 0.9 percentage points compared to a child of the same age with a sibling over the age of 14 . This represents an increase of approximately $7.0 \%$ over the pre-ban employment rate for that age group and suggests that the channels in the model are quantitatively important. Our main results from the sibling-based strategy are highly robust to a large number of checks designed to tackle possible concerns such as differential trends by birth spacing and sibling age. We then exploit state level variation in a triple difference approach to show that the employment effects are larger in areas more likely to be affected by the ban and in areas where employer inspections are more likely. Additionally, we find that the increases in child labor due to the ban are concentrated among families that appear poorer on a number of dimensions. We also find decreases in child participation in schooling. Hence, there is some suggestive evidence that the ban had negative impacts on human capital accumulation.

In line with the mechanism underpinning the theory, we find that child wages fall relative to adult wages after the ban. However, interpreting this relative wage decrease requires the assumption that there are no compositional changes on the basis of child productivity that take place after the ban. This is a key assumption, which is discussed later in Section 5.4. Finally, we examine the consequences of the ban on various key components of household welfare. If an increase in child labor raises household consumption or wealth accumulation, then the overall

\footnotetext{
${ }^{5}$ While it would be interesting to examine responses along the intensive margin, the data do not contain any information on hours worked. This issue is discussed in greater detail in Section 4, Section 5.2, and in the Online Appendix.
} 
welfare effects of the ban are harder to evaluate. We show that household asset holdings and nonstaple share of foods consumed decline after the ban (though the effects are small in magnitude). Household-level total expenditure per capita, food expenditure per capita, and caloric intake do not change in response to the ban but the estimates are precise enough to rule out any substantial positive effects. Combined with our findings for child employment probabilities, we take this as evidence that the ban makes these households unambiguously worse off along various important components of household welfare.

Our work highlights the importance of careful economic analysis of laws in a context where there could be multiple market failures (credit market failure is a prime example in this instance as noted in Baland and Robinson (2000)). There exists a rich tradition of research at the intersection of law and economics in developed countries (Commons (1924), Stigler (1992)); however, there is considerably less empirical work in developing countries. The effects of laws could be quite different in developing countries when they are not fully enforced due to weak institutions. The paper's analysis is broadly applicable to child labor bans in other developing countries where weak enforcement combined with a subsistence motive creates the potential for perverse effects. Hence, our paper speaks to the idea that optimal policy making in developing countries should take into account an environment of weak enforcement (as in the case of tax policy see Gordon and $\mathrm{Li}$ (2009)) and non-standard behavior at the margin of subsistence (Jayachandran (2006)).

\section{The Child Labor (Prohibition and Regulation) ACt of 1986}

The impetus for the 1986 law came from multiple reports from Government committees that suggested weak implementation of prior laws against child labor. ${ }^{6}$ The major innovation of the 1986 law was uniformity in the minimum age restriction - people up to age 14 were defined as children and therefore ineligible to work in certain industries and occupations. Subsequent additions to the list of industries banned from hiring children under 14 were made at various points between 1989-2008. The occupations subject to the ban after 1986 and before 1994 (the period we examine)

\footnotetext{
${ }^{6}$ The entire Act of 1986 is available easily online and also from the authors. For descriptions of these government committee reports, the Sanat Mehta Committee of 1986 and the Gurupadaswamy Committee on Child Labor of 1979, see Ramanathan (2009)).
} 
were occupations that involved transport of passengers, catering establishments at railway stations, ports, foundries, handling of toxic or inflammable substances, handloom or power loom industry and mines among many others. The list of "processes" that were banned for children includes beedi (hand rolled cigarette) making, manufacturing of various kinds (matches, explosives, shellac, soap, etc.), construction, automobile repairs, production of garments, etc. The major caveat to these bans was that agriculture was largely exempted and family-run businesses were allowed to employ their own children without age restrictions.

Importantly for our purpose, the law clearly states the penalties for employers who contravene the ban, including “... imprisonment for a term which shall not be less than three months but which may extend to one year or with fine which shall not be less than ten thousand rupees but which may extend to twenty thousand rupees or with both.” and for repeat offenders, “... imprisonment for a term which shall not be less than six months but which may extend to two years."”

Though enforcement of the 1986 law has been largely weak, it does appear that employers were aware of the law. Hard data on inspections is difficult to come by for the period we study (1987-1994). However, reporting of the law in national newspapers at the time suggests that the law was implemented immediately and with some visibility. In January 1987 a series of arrests in Ferozabad, Uttar Pradesh (an important center for bangle manufacturing) made the national news. This incident was heralded as the "beginning that has to be made somewhere in ending child labour" and social workers acknowledged that the arrests "under the child labor law would augur well for its implementation" (Times of India, January 17, 1987; pg.18). This sentiment was echoed in February 1987, as states were "told to strictly enforce the Child Labour Law" ('Implement child labor law strictly', Times of India, February 28, 1987; pg.18). Data on inspections become more widely available in later years; between 1997 and 2005, over 2.34 million inspections were carried out across India resulting in nearly 144,000 violations (IndiaStat).

\footnotetext{
${ }^{7}$ The 1986 Act did not impose any penalties on children found to be working (or their families). "Rehabilitation" of children found working - which involved forcing children into bridge schools and (at least on paper) transfers made to families of working children - was not legally required until 1996, after our period of study. The National Child Labour Project (NCLP) Scheme (which also involved forced attendance of bridge schools) was implemented in 1988, but was very small in scope until the mid-1990s; according to the Indian Ministry of Labour and Employment, until 1995-6 only 4,205 children from 12 "labour endemic" districts were affected.
} 
In response to the law and subsequent risk of inspection, many employers found loopholes to work around the specifics of the law. For example, a 2003 Human Rights Watch report provides anecdotal evidence on factories contracting with adults to take work home for their children since work at home was allowed under the terms of the law. Similarly, employers may have been able to work around the law through bribes paid to inspectors (a 1996 Human Rights Watch report confirmed that child labor inspectors were "notoriously corrupt and susceptible to bribery") or other means of thwarting the age authentication process: "Fake age certificates are produced in courts claiming the child's age above 14 years. These certificates can be bought for 100 Rs." ('Children exploited in the Land of Glass', Times of India, November 19, 1994; pg. 7) This suggests that whether through official channels (such as the threat of fines and imprisonment) or unofficial channels (such as bribes paid), one effect of the law was to increase the cost of employing children. Moreover, even for the industries/processes where child labor was not explicitly banned (including agricultural work but excluding household enterprises), the 1986 law placed additional limits on child work. ${ }^{8}$ For these reasons, the ban may have increased the cost of hiring children (and subsequently lowered child wages) for a broader set of occupations than those listed in the 1986 Act.

At the national level, while there were over 3 million inspections (turning up about 163,000 violations) between 2002 and 2008, only about 45,500 cases were prosecuted and about 8,700 ultimately ended in convictions (IndiaStat). While overall enforcement might have been weak, the anecdotal evidence on the increased threat of inspections and employers' subsequent responses leads us to believe that the media coverage and publicity surrounding the 1986 Act generated awareness of the law as the government put renewed effort into enforcing it.

\section{THEORETICAL FRAMEWORK}

In this section, we briefly describe the intuition of a basic model that illustrates the potential effects of a ban on child labor in the case where there are multiple sectors and market frictions that limit movement of labor between sectors. For a full discussion of the model see the

${ }^{8}$ For example, Section III of the law states that for every three hours of work, a child would get an hour of rest; no child shall work between $8 \mathrm{pm}$ and $7 \mathrm{am}$; and no child shall be permitted or required to work overtime. 
Theory Appendix, available from the authors upon request. The model setup builds on the onesector general equilibrium framework established in Basu (2005) and Basu and Van (1998) and the multiple-sector frictionless model established in Edmonds and Shrestha (2012b).

In the one sector case where households make decisions over the number of children to supply labor, Basu (2005) and Basu and Van (1998) show that an imperfectly enforced ban on child labor could lead to lower wages and increased levels of child labor. This prediction is generated by two basic assumptions: (i) child and adult labor are substitutable (up to a productivity shifter) ${ }^{9}$ and (ii) households send their children to work only if household income in the absence of child wages is below a subsistence constraint, and then supply only enough child workers to reach the subsistence level. ${ }^{10}$ Under these conditions and starting from an equilibrium in which some children are working, an imperfectly enforced ban lowers child wages. This is because - as suggested by the descriptive evidence in the previous section - the ban increases the costs of hiring children under the legal working age (for example, through the expectation of fines or through bribes paid to inspectors); the increased costs in combination with the substitutability of adult and child labor lead to lower wages paid to children targeted by the ban. When households rely on child labor income to meet a subsistence target, these lower wages mean that additional children must work in order to achieve that target. ${ }^{11}$ In other words, the ban lowers the wages of children who are already working and as a result, their siblings are pushed into the labor market. Thus the ban results in an increase in each household's supply of children to the labor market on the extensive margin, raising

\footnotetext{
${ }^{9}$ Existing empirical evidence suggests that employers treat child and adult labor as substitutes. See for example Doran (2013).

${ }^{10}$ Poverty has been shown to be an underlying cause of child labor in a number of contexts, including India (see Edmonds and Pavcnik (2005b)), though this is not to say that there are not other root causes (again, we refer the reader to reviews by Basu (1999), Edmonds et al. (2010), Edmonds (2007)).

${ }^{11}$ In the context of these models, assumption (ii) implies that children only work when adults in the household have already exhausted their own labor supply in an attempt to reach the subsistence level. This means that adults cannot increase labor supply in response to the ban. Since these models treat all those not legally barred from working as adults, this will imply that the model predicts there will be no effects of the 1986 ban on the labor supply of individuals over the legal working age (i.e. even on "young adults" above age 14 who are legally allowed to work). We investigate this implication empirically in Section 6.4.1. It is also worth noting that in the pre-ban period, working children (ages $10-13$ ) tend to live in households where older siblings are already working ( $72 \%$ versus $29 \%$ in households where 10 13 year olds are not working; difference significant at the 1\% level). Therefore, it appears plausible that in households with working children targeted by the ban, older siblings are unable to adjust their labor supply in response to the ban.
} 
the aggregate number of working children. ${ }^{12}$ This increase in child labor supply puts downward pressure on wages; though both adult and child wages fall in response to the ban, child wages fall proportionally more than adult wages because employers also adjust for the higher costs associated with hiring child labor due to the expected fines. One additional implication of these models is that the larger the expected fine faced by employers of children (i.e. the higher the value the fine or bribe or the higher the probability of being detected by an inspector), the larger the fall in wages for children and the greater the effects on aggregate child labor.

Extending the baseline model to two sectors requires careful consideration of the underlying labor market conditions. In particular, the existence of labor market frictions that restrict the flow between sectors is very important for the implications of policies to reduce child labor. Edmonds and Shrestha (2012b) show that in the absence of any labor market frictions, a ban on child labor in one sector has no impact on the overall level of child labor but simply reallocates child labor across sectors. The key intuition behind this result is that households are able to freely adjust on the margin of adult labor. A ban in one sector reduces the return to child work in that sector, so children flow into the alternate sector. This increase in labor supply lowers wages in the non-banned sector, so households reduce their supply of adult labor to the non-banned sector and increase supply to the banned sector until the effective wages in each sector are equalized (at pre-ban levels). Although all children will work in the non-banned sector, the marginal rate of substitution between child leisure (or schooling) and work has not changed from pre-ban levels and thus overall levels of child labor are unaffected by the ban (as long as there is sufficient adult labor to satisfy total labor demand in the banned sector). From a policy making point of view, while the fine does not achieve its goal of reducing child labor, it does not lead to the perverse outcome of increased child labor as in Basu (2005) and Basu and Van (1998).

Now consider a setting in which labor markets are imperfect such that there is limited mobility between sectors. In particular, while labor flows freely into one sector, there are some barriers to entering the other. ${ }^{13}$ As the 1986 ban largely applied to manufacturing jobs, to fix

\footnotetext{
${ }^{12}$ Both the Basu (2005) and Basu and Van (1998) models evaluate changes in child labor only on the extensive margin (i.e. on the number of working children).

${ }^{13}$ For example, the ability to find work outside the household (and in particular, child work) is likely to depend on networks based on religious, ethnic, caste, familial, or other social ties; since these are likely to be correlated with
} 
ideas we can think of the banned sector as manufacturing and the non-banned sector as including agriculture and household enterprises. In this partial mobility setting, an increased fine for hiring child labor in the manufacturing sector lowers wages in that sector. ${ }^{14}$ Unlike the full mobility case, labor cannot completely reallocate to "undo" the effects of the child labor ban; although children may flow out of the banned sector, adults cannot completely replace the children who exit that sector due to the barriers to entry. In response to their working siblings earning lower manufacturing wages, more children (who previously were out of the labor force) must work to help households reach the subsistence target. Children that enter the workforce as a result of the ban may enter either manufacturing or agriculture; since there are no barriers to entry into agriculture we might actually expect larger increases in child employment in agriculture than in manufacturing. ${ }^{15}$ Thus, after the ban, more children are working overall and all earn lower wages. In summary, when we extend the canonical model of Basu and Van (1998) and Basu (2005) to two sectors with frictions, child labor may rise and child wages may fall in response to an imperfectly enforced ban on child labor.

\section{DATA}

The data we use in the paper are from several rounds of the National Sample Survey (NSS) of India. We focus on the employment surveys (Schedule 10) of the NSS data that span the period before and after the ban. These employment rounds include the 38th (January - December 1983), 43rd (July 1987 - June 1988) and 50th (July 1993 - June 1994) NSS rounds. The employment schedule collects information on employment activities and wages in addition to household and individual level demographic data. ${ }^{16}$

particular occupations and sectors, these types of network-based restrictions might significantly limit labor mobility (see, for example, Munshi and Rosenzweig (2006)). Additionally one sector may require skills that are costly or difficult to acquire; in our empirical context, many of the occupations listed in the 1986 Act were broadly considered to be within the manufacturing sector. Even relatively low-skill jobs may require a set of basic skills that are instilled during early schooling or training (see for example the discussion of garment factories in Heath and Mobarak (2014)). ${ }^{14}$ There are several possible cases in the partial mobility setting. Here we discuss the cases in which the post-ban manufacturing wages are at least as high as agricultural wages. The other cases are discussed in the Theoretical Appendix, available from the authors upon request.

${ }^{15}$ The partial mobility case assumes that some individuals (including new entrants into the labor market) have access to both sectors, while others have access to only agricultural jobs; see the Theory Appendix for details.

${ }^{16}$ For robustness, we make use of two additional sources of data from the NSS: (1) the 42nd round which was collected between July 1986 and June 1987 and (2) the consumption rounds (Schedule 1) which were conducted only in the 
In our main analysis, we examine labor supply responses of over 317,000 children between the ages of 6 and 13 who are related to the head of the household. Table 1a presents the household level summary statistics in the rounds before (1983) and after the ban (1987-8, 19934); columns (1) and (4) display this information for the entire sample of households, while the remaining columns break down the main sample into "treated" and "control" households. ${ }^{17}$ The definition of "treated" and "control" groups is discussed in great detail in Section 5.2 and 5.5. It is worth noting that along most of the dimensions that we are able to measure, "treated" and "control" households appear similar in the pre-ban period and even when they are slightly different (see, for example, the age of the household head) the gap between treated and control households is stable from the pre- to the post-ban period. ${ }^{18}$ We calculate monthly per capita expenditures based on a 30-day recall of household consumption for a detailed list of items. ${ }^{19}$ Information is collected on both quantities and expenditures and includes home produced goods (which have expenditures imputed at the farm-gate price). ${ }^{20}$ To construct caloric intake we convert the recorded quantities into calories using the standard caloric conversion factors that have been used for this purpose in the past (Gopalan et al. (1980)). We calculate a "staple share of calories" measure as the ratio of calories from cereals and cereal substitutes to calories from all sources (following Jensen and Miller (2010)). We also construct a household wealth/asset index as the principal component of housing variables and some proxies for durable ownership.

The main measures of child time allocation we examine are based on the child's reported "principal usual activity" in the 365 days previous to the survey. These activities are reported as mutually exclusive categories. We define "Any Economic Activity" as any form of child work in any occupation, both within and outside the household, with or without pay, but excluding unpaid

years following the passage of the 1986 Act (rounds 45, 46, 47, 48 and 49 over the period 1989-1993; there are no consumption rounds available prior to 1986). For various reasons discussed in the Online Appendix, we do not include these in our main analysis.

${ }^{17}$ The sample of households we use to calculate the summary statistics is the set of households containing at least one child age 6-13 with at least one sibling age 6-17 (the samples for our main sibling-based results).

${ }^{18}$ In Section 6.1, we conduct formal tests of whether the demographic characteristics of households change differentially across treated and control households from the pre- to the post-ban periods.

${ }^{19}$ Household expenditure data are directly linked to the employment data in 1983, 1987-8, and 1993-4 (both Schedules 1 and 10 were collected in those rounds).

${ }^{20}$ Real values (in 1982 rupees) are nominal values deflated by the average wholesale price index reported by the Government of India for the respective year. For additional details on all variables, see the Online Appendix. 
household chores performed for one's own family (reported separately as "Unpaid Household Services"). Children "Attending School" are those whose primary activity is attending school. The NSS also contain data on the days spent in each activity during the previous week in half-day increments (note the difference in recall period relative to "principal usual status"). However in practice the data on days yield very little variation over and above the extensive margin. Figures OA1 and OA2 display the distribution of days spent engaged in economic activities and attending school, respectively, for children in 1983 (before the ban). Clearly there is significant heaping at 0 and 7 days for both schooling and work ${ }^{21}$; the latter is especially troublesome as it is practically impossible, as the standard school week is 5 days in India. Therefore, though families may respond to the ban by increasing the days each child works, the number of working children, or both, we are only able to examine the effects of the ban on the principal usual activity which largely captures the extensive margin of child work. ${ }^{22}$

Columns (1) and (4) of Table 1b give the child level summary statistics for the overall sample of 10-13 year old children separately for the pre-ban and the post-ban periods. Child schooling is rising over time and participation in economic activities is falling. ${ }^{23}$ We plot work probabilities by age (for children 10-17, the age range used for our simple difference-in-difference estimates) and sample period in Online Appendix Figures OA4 and OA5. Figure OA4 displays the raw probabilities of economic activity by age, separately for the pre-ban and post-ban periods, whereas Figure OA5 displays the same, but adjusted for the effects of observable characteristics. The simple difference-in-difference estimate is apparent even in the raw work probabilities, as those under the age of 14 (i.e. those targeted by the ban) decrease their participation in economic activity by less than those just over the legal age limit. After taking into account the role of covariates, children under the age of 14 are no less likely to participate in economic activities after the ban (if anything, they are more likely to work) while the probability of work declines for those age 14 and over after the ban.

\footnotetext{
${ }^{21}$ The heaping at 0 and 7 is very pronounced even when the data is disaggregated into smaller age groups.

${ }^{22}$ See Section 5.2 and the Online Appendix for more discussion on how our results may capture both intensive and extensive margin movements.

${ }^{23}$ Measurement error in employment status, including strategic underreporting of child labor, is discussed in Section 6 , where we also address other potential threats to the validity of the empirical strategy described in the next section.
} 
The remaining columns in Table $1 \mathrm{~b}$ show the child-level statistics by our sibling-based treatment status where treated children are expected to display a larger response to the ban. Here, we can observe the foundation for our main result; the economic activity of treated children falls by less than economic activity of control children, after the ban is in place. Online Appendix Figures OA6 and OA7 display the raw and residual changes (respectively) in child participation in economic activity from the pre- to the post-ban periods separately for treated and control children and by (own) age. For most ages, treated children experience a smaller decline in work probabilities than control children.

Table $1 \mathrm{~b}$ also shows that the majority of economically active children are engaged in some form of work within the household rather than for an outside employer. About 8-10\% of working children are employed in occupations banned under the 1986 Act, depending on the survey period. We classify children as working in banned versus non-banned occupations based on the 3-digit NIC codes reported for each employed child. These are matched to the list of processes and occupations listed as banned in the 1986 Act. $^{24}$ The definition of banned occupations that we use explicitly excludes any work in family enterprises or other home-based production, as any work within a family business was considered exempt under the 1986 Act regardless of the NIC code. Conditional on being principally engaged in economic activities, children report working a high number of work days on average (between 6.1 and 6.4 days in the past week) and subsequently very little time spent in other activities such as schooling and unpaid household duties.

\footnotetext{
${ }^{24}$ Over time, additional occupations and processes have been added to the banned list though very few additions occur between 1986 and 1993. The majority (and more substantive) of the changes occur after 1993, including the prohibition of child employment in domestic work and dhabas (eateries) which were added in October 2006.
} 


\section{EMPIRICAL STRATEGY AND RESUltS}

\subsection{Simple DID estimates of the effects of the ban on child time allocation}

To assess the overall effects of the 1986 Act on child time allocation, we begin by running the following basic difference-in-difference specification:

$$
\begin{aligned}
& Y_{i t}=\gamma_{0}+\gamma_{1} \text { Under } 14_{i}+\gamma_{2} \text { Post } 1986_{t} \\
& +\gamma_{3}\left(\text { Under } 14_{i} \times \text { Post } 1986_{t}\right)+\gamma_{X} X_{i t}+\delta_{t}+\theta_{q}+\nu_{i t}
\end{aligned}
$$

$Y_{i t}$ represents a measure of child time allocation such as work or schooling for child $i$ in survey round $t$. Under $14_{i}$ is a dummy variable for under 14 (legally barred from working after the enactment of the 1986 Act). Post $1986_{t}$ is a dummy variable that is 1 for all periods after December 1986. In order to ensure that our above- and below-14 age groups are as comparable as possible (while maintaining enough age groups for credible estimation of standard errors) we restrict our estimation sample to those children between the ages of 10 and $17 .^{25} X_{i t}$ is a vector of household- and child-level covariates, such as characteristics of the household head and fixed effects for gender, state, household size, etc.; a full list of covariates appears in the notes below each table. In practice, we also include age fixed effects, so $\gamma_{1}$ is not separately identified. $\delta_{t}$ represents survey round fixed effects (and thus $\gamma_{2}$ is also not separately identified) and $\theta_{q}$ captures quarterly seasonality through quarterly dummies. In our main results we cluster our standard errors by age-survey round though our results are robust a number of alternate clustering approaches; see Online Appendix Table OA $1 .^{26}$

Our coefficient of interest is $\gamma_{3}$, which captures the differential change in child time allocation after the ban is in place, for children under the legal working age versus children of legal working age. The identifying assumption in (1) is that in the absence of the ban, the difference in outcomes for those above age 14 and those below age 14 should be stable over time. Under

\footnotetext{
${ }^{25}$ Our main results use the sample of all children ages 10-17 who are related to (and residing with) the household head; they are robust to using a restricted sample of only those who are listed as unmarried children of the household head. The results are also robust to using a restricted sample of households that contain at least one child aged 10-13 and one child aged 14-17. Results available upon request.

${ }^{26}$ See Online Appendix Section 2.1 for details on the implementation of the Wild Cluster bootstrap procedure.
} 
this assumption, the pre-ban to post-ban shift in relative child time allocation for those under 14 relative to those over 14 - controlling for other observable characteristics, general time trends, and seasonality - is then attributed to the ban. As with any difference-in-difference strategy, the validity of this assumption is essential to interpreting our estimates as capturing the causal effects of the ban. ${ }^{27}$ Given that the period under study (1983-1994) was one of substantial change in India, there are reasons to believe that younger and older children may have been on been on differential trajectories, even prior to the 1986 Act. With only one pre-period survey round, we are unable to test for such pre-existing differences. However national-level data from 1977-78 suggest that preban trends in labor force participation were parallel for broad age groups that roughly correspond to the ban's target; on the other hand, the trends clearly diverge beginning in 1987-8 (the two years immediately after the passage of the Act), when child labor stagnates and remains steady while young adult labor declines. Note that these national data are published in pre-defined age groups (which we are not able to choose ourselves); these age groups are very wide and do not strictly conform to the age restriction of the 1986 Act, but data containing more narrowly defined age groups are not available. ${ }^{28}$ Those caveats aside, to the extent that we are able to examine pre-ban trends by age group, we do not see any evidence of non-parallel trajectories. Nonetheless, we view the results of estimating (1) as mostly suggestive and subject to strong identifying assumptions that may or may not be satisfied. Instead, we regard two alternate strategies as representing our main empirical specifications: one that uses sibling age to identify the income effect of the ban (Section 5.2) and one that exploits geographical heterogeneity in a triple-difference setting (Section 5.3). Nonetheless, we believe that this basic difference-in-difference strategy is still useful as a starting point for understanding the effects of the 1986 Act.

\footnotetext{
${ }^{27}$ An alternative strategy would be to implement a regression discontinuity (RD) design in which we compare children just below the cutoff of age 14 to children just above the cutoff. However, we do not pursue an RD approach for our baseline estimates for several reasons: (i) low number of age bins (8); (ii) steep age gradient in work probabilities, leading to large differences in pre-ban work probabilities "close" to the cutoff (iii) significant heaping in reported ages (not systematically related to the ban).

${ }^{28}$ Household- and individual-level NSS data are only available starting with the 1983 round. However, national-level data on labor force participation by age group is available for the 1977-78 round of the NSS. Online Appendix Figure OA8 displays these national trends from 1977-1994 separately for ages 5-14 and ages 15-29.
} 
The results of estimating (1) on the the main sample are displayed in Table $2 .^{29}$ The first two columns report the results for the main outcome of interest, "Any Economic Activity", excluding and including additional controls, respectively. While the addition of controls greatly increases precision, the point estimate is very stable across specifications with and without covariates. ${ }^{30}$ The coefficient reported in column 2 indicates that the ban was associated with a 2.6 percentage points increased in the probability of participation in economic activity for children under the legal working age relative to those aged 14-17 (a 22\% increase over the pre-ban mean for children ages 10-13). When we decompose this rise in employment into various categories of work, we find that while the majority of the increase is in non-banned occupations ( 2.3 percentage point increase, column 4), there is also a small but statistically significant increase in work in banned occupations (0.4 percentage point increase, column 3). In other words, though the ban was introduced to lower child labor in a specific set of occupations, these results indicate that the employment of children under the age of 14 (relative to those of legal age) rose in exactly those occupations. Columns 5 and 6 illustrate that the majority of the increase in employment is in paid work, consistent with the idea that households are in greater need for income generated by child work as a result of the ban. There is a small and statistically insignificant association for school attendance (column 7), and the ban seems to have decreased the incidence of unpaid household services (column 8). ${ }^{31}$

While strong assumptions are needed to interpret the coefficients reported in Table 2 as causal effects of the ban, the simple estimates are robust to some important checks. First, we estimate (1) using samples of children with increasingly narrow age ranges. ${ }^{32}$ The idea is that

\footnotetext{
${ }^{29}$ The results in this section are robust to adding the additional consumption rounds of the NSS as well as to including more flexible age controls to capture potential differential trends by age group over time. The age controls we consider are round-specific quadratic trends in age (i.e. quadratic trends in age that are estimated separately for 1983, 1987-8, and 1993-4), age-specific linear time trends (i.e. linear time trends separately for each age), and a complete set of age interactions (linear, quadratic and cubic age trends that are allowed to be different for those under and over 14, separately for the pre- and post-ban periods). They are also robust to defining the extensive margin of participation using indicators based on whether days spent in each activity are greater than 0 . The results of these exercises are available upon request.

${ }^{30}$ The coefficient of interest becomes significant at the $1 \%$ level as soon as age fixed effects are added to the model.

${ }^{31}$ It is important to recognize that schooling and work are not the only activities that children may engage in. There is a substantial literature on "idle" children, i.e. those who report neither being in school nor in economic activities (see for example Edmonds and Pavcnik (2005a), Biggeri et al. (2003) and Bacolod and Ranjan (2008)). As discussed in Edmonds et al. (2010), policies affecting child labor may also impact idleness of children.

${ }^{32} \mathrm{An}$ alternative to narrowing the age band is to use triangular weights centered on ages 13/14 which give more weight to observations closer to the legal working age cutoff and lesser weight to very young children and young adults. The
} 
the narrower the age band, the more likely the data are to satisfy the parallel trends assumption and the less concerned we are with potential "floors" in child work, i.e. the possibility that child employment for those under 14 is mechanically less likely to fall because it starts from a lower pre-ban level. Appendix Table OA2 shows that the point estimate remains positive and significant for all but the narrowest age range, the sample that contains only 13 and 14 year olds. ${ }^{33}$ When we use the narrowest sample, the point estimate remains positive but is considerably smaller and no longer statistically significant. ${ }^{34}$ Next, we estimate (1) using a narrower time window around the implementation of the ban. The simple estimates are robust to shortening the period of study to 1983-1988 (rather than 1983-1994) by using only one of the post-ban rounds (results available upon request). Another way to narrow the sample period is to use the 42nd round of the NSS which spans the six months immediately before and after the ban. ${ }^{35}$ We do not use the 42nd round in our main analysis because the definition of economic activity in the 42nd NSS round differs substantively from the definition in the other rounds; specifically it does not contain any information on economic activity for any child currently enrolled in school regardless of principal activity (see the Online Appendix Section 1.2 for more details). The results of estimating (1) on the 42nd round are displayed in Appendix Table OA3. ${ }^{36}$ The effect of the ban on child economic activity is positive but much smaller than in the main sample ( 0.3 percentage points, Column 2$)$ and not statistically significant. We do find a small, statistically significant increase in paid work (Column 5) but not for any other measure of economic activity.

\footnotetext{
simple estimate remains large, positive, and statistically significant even after the use of triangular weights. Results available upon request.

${ }^{33}$ To reflect the correct level of precision of our estimates we use a Wild Cluster Bootstrap procedure (Cameron et al. (2008)) with Webb weights to adjust for the low number of clusters (Webb (2013)).

${ }^{34}$ As the age range narrows, the scope for attenuation due to measurement error in "treatment" may increase if employers find it more difficult to distinguish between eligible and ineligible children when they are closer in age.

${ }^{35}$ Anecdotal evidence presented in Section 2 suggests that the 1986 Act was implemented immediately, leading to highly publicized arrests as early as January 1987. However, we might expect smaller estimated effects using this 1-year period for several reasons, such as: (i) there may have been some delay in either implementation or household responses to the ban or (ii) there may have been anticipatory effects of the ban in the six months leading up to implementation and (iii) seasonality in child labor that may be confounded with the effects of the ban.

${ }^{36}$ Narrowing the analysis to a short period of time also limits the influence of potential "floors" in child work, as we do not observe large changes in child labor for either age group in this period.
} 


\subsection{Sibling-based estimates of the effects of the ban on child time allocation}

As discussed in the previous section, one drawback to the estimates in Table 2 is that interpreting them as causal effects of the 1986 ban requires strong assumptions about parallel trends in economic activity for younger and older children that may not be satisfied. Moreover even if the assumptions hold, the basic difference-in-difference strategy estimates only the overall policy impact of the 1986 ban and does not isolate a specific channel through which the ban affects children. To strengthen our empirical approach and tie our empirical results more strongly to the theoretical predictions outlined in Section 3, we now turn to our main estimating strategy which uses sibling ages to identify the impact of the ban. According to the model, a ban reduces wages for children under the legal working age. For households reliant on child labor income, this decrease results in a pure income effect on the labor supply of siblings of working children. Recall that in the Basu (2005) and Basu and Van (1998) frameworks, child labor supply is modeled on the extensive margin so the most direct interpretation of these theories is that the ban reduces wages paid to working children, and in response, their siblings (who were previously not working) must enter the workforce to make up for the decrease in household income. Thus we expect that the effects of the ban on child employment through this channel should be largest in households that depend on child labor, i.e. households with working children under the legal age. ${ }^{37}$

To isolate the income channel empirically, the basic design would be to compare the employment status of children of the same age with working siblings under 14 to those with working siblings over 14. However, we do not pursue this naive approach because the work status of siblings is endogenous to the ban. Instead, we rely on the age of siblings as a proxy for endogenous "treatment" of having a working sibling who becomes age ineligible for work as the result of the ban. To capture children whose siblings are likely to be working, we first define our treatment variable as requiring a child to have a sibling at least 10 years of age. We do this because in 1983 only $1.6 \%$ of children under the age of 10 are working as compared to $19.5 \%$ children ages $10-17$;

\footnotetext{
${ }^{37}$ Note that in the Basu (2005) and Basu and Van (1998) models, adult wages fall in equilibrium in response to the ban. This means that household income falls in all households, regardless of whether there is a working child in the household. The strategy laid out in this section identifies the differential effect of the ban on children with siblings likely to be working.
} 
consequently children whose siblings are all under age 10 are unlikely to be affected by the ban simply because their siblings are not likely to be working. The second requirement of our treatment variable is that it capture only children whose siblings' wages would be directly impacted by the ban, i.e. whose siblings are under the legal working age of 14 . Thus we define our sibling treatment variable to be 1 if a child has a sibling who is at least 10 but under 14 because we think this captures a child whose sibling is both likely to be working and to be affected by the ban. Specifically the regressions we use to capture the sibling-based effects of the ban are of the form

$$
\begin{aligned}
Y_{i t}=\beta_{1} \text { SibUnder } 14_{i}+\beta_{2}{\text { Post } 1986_{t}}_{t}+\beta_{3}\left(\text { SibUnder } 14_{i} \times{\text { Post } \left.1986_{t}\right)}^{25}\right. & \\
& +\beta_{X} X_{i t}+\sum_{a=0}^{25}\left(\mu_{a} \times \text { Number of Siblings of Age } a\right)+\delta_{t}+\theta_{q}+\varepsilon_{i t}
\end{aligned}
$$

where $Y_{i t}, \operatorname{Post}_{1986}, X_{i t}, \delta_{t}$, and $\theta_{q}$ are as defined in equation 1. Recall that $X_{i t}$ includes (own) age fixed effects; in order to flexibly control for the direct effects of sibling age composition, we also include in equation 2 a separate variable for each age (0-25) that counts the number of related household members of that age. ${ }^{38}$ Again, SibUnder $14_{i}$ is a dummy variable taking the value of 1 when the child has at least one sibling who is both underage in the eyes of the law and likely to be working, which we define to be a sibling at least 10 but under $14 .{ }^{39}$ Defining our "treatment" variable in this way ensures that our "control" children are those that could have older or younger siblings (i.e. any children without siblings in the "treatment" age range of 10-13). ${ }^{40}$ Table $1 \mathrm{~b}$ shows that "treated" children are much more likely to be living with a working sibling under the age of 14; for example, in the pre-ban period, about $11.6 \%$ of "treated" children aged 10-13 live with an underage working sibling whereas only $1.6 \%$ of "control" children (of the same age) do. To allow

\footnotetext{
${ }^{38}$ In order to be conservative and capture all possible direct effects of sibling age, we include a wide range of "sibling" age controls; however, we use a much narrow age range (6-17) to define sibling-based treatment and inclusion in the main sample. The choice of sibling age ranges to define our treatment and sample are discussed in great detail later in this section and in Online Appendix Section 2.2. See Section 6.1 for additional robustness checks to address issues regarding sibling age composition and spacing.

${ }^{39}$ In the data we observe only whether and how individuals are related to the household head rather than direct sibling links. In the estimation we treat all co-resident relatives of the household head between the ages of 6 and 17 as siblings. This choice of age range to define siblings is important and is discussed later in this section and in Online Appendix Section 2.2. Nonetheless, our results are robust to restricting our estimation sample to only confirmed siblings using only the sample of unmarried children of the household head; see column (6) of Appendix Table A.1.

${ }^{40}$ We specifically address issues related to birth spacing and other potential effects of sibling age structure in Section 6.1
} 
for differential effects of the ban for very young children, we estimate equation (2) separately for 10-13 year olds and 6-9 year olds. The standard errors for the sibling-based estimates are clustered at the family-level, as the "treatment" of having a sibling in the right age range to be affected by the ban is correlated across children within the same household. However, the results discussed in this section are very robust to allowing for spatially concentrated unobserved shocks (state-level clustering); results available upon request. In this setup, $\beta_{3}$ captures the "intent-to-treat" effect of the ban on children rather than the "treatment-on-the-treated" effect because we do not use the endogenous work status of siblings. The sample we use to estimate equation 2 includes all children who have at least one sibling between the ages of 6 and 17. This range for sibling ages is necessary for several reasons; the most important is that this sibling-based strategy requires a symmetric sibling age range in order to avoid bias. Specifically, we need to define the set of control children (who lack a sibling age 10-13) such that their siblings could be either younger or older, as sibling age affects own work status (our main outcome of interest) even in the absence of the ban. This rules out the possibility of using an unbalanced sample, such as one where we consider only children with siblings age $10-17 .^{41}$

It is important to note that the identifying assumptions needed for the sibling-based regressions are potentially much weaker than those needed for estimating the overall impact of the ban (equation 1). The assumption in the sibling-based regressions is that in the absence of the ban, the difference in outcomes for those with and without siblings aged 10-13 will be stable over time, conditional on own age. In other words, our sibling-based regressions are comparing the changes in time allocation for children of the same age who happen to have siblings of slightly different ages (either older or younger). This strategy allows us to construct a much more similar "control" set of children who are less likely to be on a differential trajectory in the absence of the ban or to be affected by the ban through channels other than the income effect predicted by the model. ${ }^{42}$

\footnotetext{
${ }^{41}$ For more details, please see Section 2.2 of the Online Appendix. In column 4 of Online Appendix Table A.1 we show that our results are robust to using a narrower sample defined as those with at least one sibling age 8-15.

${ }^{42}$ In the Basu (2005) and Basu and Van (1998) models, there are general equilibrium effects of the ban; notably, adult wages fall so child labor rises in all households. In our context, this could mean that even children without working siblings suffering a wage loss could be indirectly affected by the ban; see Bugni (2012) for a nice example of the issues encountered while estimating difference in difference models when the "control" group is also affected. Thus our estimates in this section identify the differential effect of the ban that is due to the direct income loss due to a drop in sibling wages.
} 
Moreover, because of the way we define "treated" children (having a sibling ages 10-13) and the symmetric way in which we choose to define siblings, our "control" set includes children with both younger and older siblings, making it unlikely that our results are simply capturing changes over time that affect older and younger families differently; nonetheless, we examine and rule out other potential differences due to sibling age and spacing in Section 6.1. Finally, since our sibling regressions compare children of the same age and thus the same pre-ban likelihood of work, we are not concerned with any potential "floor" effects, i.e. the possibility that child employment for those under 14 is mechanically less likely to fall because it starts from a lower pre-ban level.

Table 3 displays the results for estimating our main specification in (2) for both the very young (ages 6-9; Panel A) and the young (ages 10-13; Panel B) samples of children. We find that through the sibling channel, the ban increases the likelihood of a child engaging in any form of work by 0.6 percentage points for the very young and by 0.8 percentage points for young children (column 1 in both panels). ${ }^{43}$ These represent $37.5 \%$ and $7 \%$ increases over the pre-ban mean, respectively. ${ }^{44}$ As with the overall estimates, the sibling-based estimates are larger for work in nonbanned occupations than in banned occupations (columns 2 and 3). In fact the effect on work in banned occupations is a precisely estimated zero. Most of the increase in employment comes from work in household production (column 4). We observe negative effects of the ban on attending school for both age groups, though the effect is larger and statistically significant for only the very

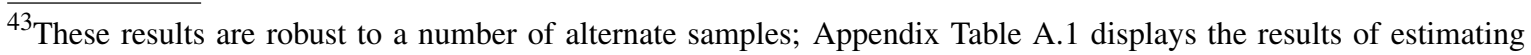
(2) on (i) the sample including additional consumption rounds of the NSS (ii) Round 42 (July 1986 - June1987) (iii) the sample that excludes children whose "treatment generating sibling" (i.e. sibling between the ages of 10-13) is younger (iv) the sample of children with at least one sibling ages 5-18 and (v) the sample that includes only unmarried children of the household head (and their siblings). These sibling effects are also robust to alternately dropping Round 43 (1987-8) or Round 50 (1993-4); see Online Appendix Table OA7.

${ }^{44}$ Again, these sibling-based results help us rule out some potential concerns with our simple difference-in-difference approach. For example, if there were other policies during this period that were aimed to increase school enrollment and reduce economic activity of older children, our basic difference-in-difference model would confound the effects of these policies with the 1986 Child Labor Act and overstate the effects of the Act. This sibling-based approach avoids this bias by comparing children of the same ages. Moreover, if such policies drew older children out of the labor force, we would expect income-constrained households to replace the lost income with the labor supply of other children, i.e. siblings of older children would be more likely to work in the post-ban period relative to the pre-ban period. In fact, we find that only siblings of those targeted by the ban (under the age 13) are more likely to work after the ban is in place. Therefore the sibling-based results are not consistent with coincident schooling interventions targeted towards older children.
} 
young (column 6). Time spent in unpaid household services increases for the very young but not for the young (column 7).

While the effects of the ban may initially seem large the magnitudes are plausible for several reasons. First, as discussed in Section 2, though the age restriction officially applied to only a certain set of industries, the 1986 Act also imposed a number of regulations on child labor that were likely to raise the cost of hiring children even in industries where they were legally allowed to work. Therefore, the Act may have affected a wider set of working children than just those working in industries subject to the age restriction for employment. Second, it is possible that these estimates capture both intensive and extensive margin changes in economic activity. This is because child time allocations are based on principal activity; some of the increases in economic activity reflected in Tables 2 and 3 could be due to children who were primarily focused on non-economic activities (unpaid household services, school, etc.) before the ban but shifted on the intensive margin in a way such that economic activities became the principal activity in the post-ban period. Online Appendix Figure OA3 gives supportive evidence for this interpretation. It shows that among children aged 10-13 in the pre-ban period whose principal usual activity is not working, there are a number of children who work between 1-6 days per week; if the ban were to induce these children to work even a few more days, their principal activity may switch to work and thus be captured in our main results. ${ }^{45}$ To investigate this further, we present the results of estimating our sibling-based regressions using days spent in each activity in the previous week in Online Appendix Table OA4. One must interpret these results with caution, given the heaping in the distributions of the outcome variables discussed in Section 4 and seen in Figures OA1 and OA2 in the Online Appendix; the days data clearly represent mostly extensive margins of participation. With that caveat in mind, Online Appendix Table OA4 shows that the effects are very similar to the baseline results obtained when using principal usual status to define outcomes. The qualitative patterns in the results mirror those of Table 3, but the magnitudes suggest small average changes

\footnotetext{
${ }^{45}$ The mass of children who worked 7 days in the previous week but whose principal status is not working may be due to the difference in recall periods (previous 365 days to the survey for principal usual status versus previous 7 days for days spent in each activity). Only $1.2 \%$ of children whose principal status is not working report non-zero work days in the past week.
} 
in days worked in response to the ban. ${ }^{46}$ For children ages 10-13 (ages 6-9), the ban increases the days spent working in the previous week by only 0.06 days ( 0.025 days) on average but if the effect were concentrated among those "marginal" children who spent some time working but whose principal status in the pre-ban period was not working, it is plausible that it would be enough to induce a change in principal status. ${ }^{47}$

\subsection{Heterogeneity}

Though the 1986 Act was applied nationally, there is reason to expect that the ban had heterogeneous effects across geographical areas. In particular, we might expect the impacts of the ban to be larger in areas where the banned industries were more crucial to local labor markets. The theoretical models from Section 3 also indicate that the effects of a ban should be stronger the higher the probability of detection by inspectors. In addition, one concern with the analysis so far is that in analyzing a national change using a difference in difference approach, we might be allowing other policies or events that happen to coincide with the 1986 Child Labor Act to influence our results. In order to tie our empirical results to the theoretical model and to provide additional evidence that the ban - rather than other confounding factors - is driving our estimated effects, we now turn to methods that exploit geographical variation specific to the ban.

Our first measure of geographical heterogeneity calculates the importance of the ban as the proportion of households in each state that are principally engaged in an industry which is listed in the 1986 Act. In particular, we use the pre-ban data to calculate the proportion of households within each state that derive income mostly from banned industries to capture the importance of banned industries to local labor markets. As can be seen in Table 1a, about $11.4 \%$ of households

\footnotetext{
${ }^{46}$ Due to data limitations, the classification of activities into banned versus non-banned occupations is much coarser in Online Appendix Table OA4 than in Table 3. In particular the former uses 1-digit NIC codes while the latter uses 3-digit NIC codes; both classify any work in household enterprises and farms as non-banned work.

${ }^{47}$ They are also robust to defining the extensive margin of participation using indicators based on whether days spent in each activity are greater than 0 (with one exception - the effect of the ban on school attendance for children ages 6-9 is no longer significant using this definition of the extensive margin); results available upon request. The data also contain limited information on secondary activities. In particular, secondary activities are only reported if they are gainful and thus exclude schooling and unpaid household services. In the pre-ban period, $4.4 \%$ of all children ages 10-13 who are primarily engaged in non-economic activities such as school report some form of gainful secondary activity. This suggests a non-negligible pool of children whose primary activities could shift from non-work to work due to an increase in work hours resulting in a new primary activity classification, suggesting that our results could indeed capture a considerable intensive margin effect of the ban.
} 
nationally are primarily engaged in activities listed under the 1986 Act but at the state level this ranges from $0.7 \%$ to $28.2 \%$, indicating considerable geographical heterogeneity. We classify states into high and low importance states based on the pre-ban median of the importance measure across all states. Columns 1 and 2 of Table 4 display the results of estimating equations (1) and (2) in a triple difference approach, with additional interaction terms to capture the differential effect of the ban in states with high (pre-ban) importance of banned industries ${ }^{48}$; as we are now using statelevel variation to identify the effect of the ban, standard errors are clustered at the state-level. In states where banned industries are likely to be more important to the local labor market, the overall effect of the ban is 0.8 percentage points larger but this difference is not statistically significant at conventional levels; in those same states, the sibling-based effect is 1.5 percentage points larger (significant at the 5\% level). In fact there is no statistically significant sibling effect in states with low importance of banned industries.

The second measure of geographical heterogeneity we employ is based on the probability of detection faced by employers who hire child labor. To calculate this, we make use of state-level data on the (total) number of inspections for illegal child employment during the period 19972005. We scale the number of inspections by dividing by the the number of children working as of 1983 in occupations that would be banned under the 1986 Act. ${ }^{49}$ We then separate states into high (above median) and low (below median) enforcement states based on this measure. One potential issue with this measure of enforcement is that the data on inspections is collected well after the employment data we use for this analysis. Thus the main caveat involved with this measure is that we need to assume that the ranking of states along this measure of importance does not change between 1986 and 2005 (in particular, the classification of states as above- or below-median). With that in mind, the results of the triple-difference regression are displayed in Columns 3 and 4 of Table $4 .{ }^{50}$ The ban significantly increases the probability of economic activity for those under the legal working age (relative to those of legal working age), and this effect is 1.5 percentage points

\footnotetext{
${ }^{48}$ All regressions include interactions between the measure of heterogeneity and all controls.

${ }^{49}$ Though this measure captures the relative probability of inspection, it can be greater than 1 if the state-level number of inspections in the period 1997-2005 exceeded the number of children that report working in banned occupations (as of 1986) in the 1983 survey round.

${ }^{50}$ The correlation between the importance and probability of inspection indicators is 0.365 .
} 
higher in states where the probability of detection is high (significant at the $10 \%$ level). Similarly, when the probability of inspection is high, the sibling-based effect is large (1.4 percentage points; significant at the $5 \%$ level), and there is no effect in low-inspection states. Both sets of results in Table 4 help us rule out potential confounding factors that do not vary systematically across states, such as differential time trends for children above and below the age cutoff, other national events or policies that may have occurred around the time of the ban, as well as "floors" in child work discussed in Sections 5.1 and 5.2..$^{51}$

Moreover, in the canonical Basu (2005) and Basu and Van (1998) models, the driving force behind families' decision to employ their children is the need to reach subsistence levels of consumption. Those who are most likely to resort to child labor before the ban and thus be affected by the ban are those with low incomes. In the Online Appendix, we show that for various proxies of household income (education of the household head, non-staple share of foods consumed, and scheduled caste status) both the effects of the ban are considerably larger in magnitude for households that appear to be poorer (though the level statistical significance varies across measures used; see Online Appendix Table OA5). Admittedly the evidence of heterogeneous impacts of the ban is only suggestive of household income as a channel for the effect of the ban, as these proxies for income could be correlated with other attributes of the household and baseline levels of child labor differ greatly across groups (we do not claim that these triple-interacted specifications identify causal effects). Nonetheless we believe that the weight of the evidence in this section favors the interpretation that, as predicted by the theoretical model, those households closer to the margin of subsistence are affected by the ban to a greater degree than those well above the subsistence threshold.

\footnotetext{
${ }^{51}$ The pre-ban proportions of child workers varies substantially by state (from $0 \%$ to over $44 \%$ ). Pre-ban proportions were similar across high and low importance and probability of detection states: $11.3 \%$ versus $10.8 \%$ in high versus low importance states, respectively; $14.4 \%$ and $14.5 \%$ in high versus low probability of inspection states, respectively (note that the inspection data are not available for all states). Moreover these results are robust to including a measure of the pre-ban incidence of child labor as well as all interactions between this measure, Under14, and Post; results available upon request.
} 


\subsection{Effect of the ban on wages}

One of the predictions of the theoretical model in Section 3 is that the wages of children will fall relative to adults' wages in response to the ban. In the NSS, wages are only reported for those engaged in regular or casual labor. Notably, this excludes children working in home enterprises and farms. Other groups that have wages recorded as zero include the unemployed, those working but unpaid, the self-employed, and beggars and prostitutes. Therefore the wage regressions are subject to the usual caveat - particularly important in developing countries and when examining wages of children - that they only apply to a select subsample of workers. While it is important to recognize the limitations of the wage data, our results will still be informative about the wages of those engaged in work outside the household, which is the focus of the theoretical models in Basu (2005) and Basu and Van (1998). The results of estimating equation (1) on various samples are displayed in Table 5. We see a substantial drop in child wages relative to adult wages; once we control for observable individual characteristics the effect of the ban is to reduce child wages by $7.8 \%$ on average (column 2). ${ }^{52}$ Due to the very low number of wage observations, we widen our age band for these wage specifications only; the size of our main estimation sample (ages 10-17) drops by $96 \%$ when we restrict it to observations with reported wages. Columns 3-6 of Table 5 illustrate that these wage results are robust to narrower age ranges, though with some loss in precision for the narrowest band ( $\mathrm{p}$-value $=0.109$ )

One potential explanation for our wage findings is a wage-earning workforce composition effect due to the rapid economic growth India experienced during the period under study. In Section 3 we assume that all children are equally productive and earn the same wage. In reality, we might expect households to withdraw the least economically productive children as their incomes rise, as these children are likely to be paid less and are therefore less important to household income. If this type of positive selection on skills into paid work outside the household becomes stronger over

\footnotetext{
${ }^{52} \mathrm{We}$ do not analyze heterogeneous effects of the ban on wages by occupation. This is because selection into different occupations of work is likely to be shifting differentially over time for those over and under age 14. Online Appendix Table OA6 illustrates this point. It displays the proportion of working individuals that report wages by sector and age group. While all children under 17 become less likely to report wages after the ban, the largest drop in wage reporting is for children under 14 in banned occupations. Thus we believe this differential selection in wage reporting will distort any estimated wage effects of the ban by sector.
} 
time then any composition effect should work in the opposite direction of the ban; in other words, as the composition of children in the paid workforce favors more skilled children, the smaller the difference between child and adult wages we should observe. On the other hand, if we believe that the selection into paid work outside the household is negative (i.e. the lesser skilled children are more likely to engage in the paid workforce) and this negative selection becomes stronger over time, our estimated impact of the ban on wages could be confounded with this compositional change. However, to the best extent that we are able to measure skill (using education) we find no evidence of changing selection into the workforce over time (results available upon request). ${ }^{53}$

\subsection{Effect of the ban on household outcomes}

We next turn to the impact of the child labor ban on various indicators of household welfare. The net effect of the ban - lower child wages and subsequent increase in supply of child work - on household income and consumption in our empirical context is unclear for several reasons. First, households that are unable to increase child labor supply could experience a decline in consumption to below "subsistence" levels. Second, if one of the responses to the ban was a shift from banned wage labor to household enterprise labor, we cannot observe the implicit wage and whether it declines like the market wage following the ban. Third, if households have other mechanisms for dealing with a drop in income due to the child labor ban, such as selling assets or reallocating expenditures across different types of goods, we may observe the effect of the child labor ban along some dimensions (declining assets, declining expenditures, or declining food quality) but not along others (such as the per capita calorie intake of the household).

Our approach is thus to look at changes along multiple components of household welfare for households that are more or less affected by the ban. ${ }^{54}$ We construct five household-level welfare measures as described in the data section (and described in greater detail in the Online

\footnotetext{
${ }^{53}$ Another alternate explanation for our wage results could be that the results capture an average decline in wages for children due to skill-biased technical change. If skills are positively correlated with age, we might expect that skillbiased technical change may reduce wages more for younger individuals (under 14) than older individuals (over 14), leading to decreases in wages and increases in child labor independent of the ban. However, if anything we find that the return to education declines over this period for this sample (results available upon request), consistent with earlier work (Dutta (2006) and Bargain et al. (2009)). Additionally when we allow the effect of education to vary over time by interacting education variables with "Post1986", our wage results are unchanged (results available upon request). ${ }^{54}$ Our sample size varies slightly across our household-level specifications as some of our welfare measures are undefined for some households (e.g. recorded expenditures or calories are zero, asset information is missing).
} 
Appendix). Given that our welfare measures are at the household level, we define treatment in a similar way as in equation (2), namely that "treatment" is an indicator for having at least one child aged 10-13. ${ }^{55}$ In Table 6, we find a negative point estimate of the ban's effect on all households outcomes, with the exception of caloric intakes. ${ }^{56}$ The effects of the ban are statistically significant for both our indicator of the quality of calories (1 - Staple Share of Calories) and the asset index (columns 4 and 5) though they are small in magnitude. After the ban, non-staple foods make up about a 0.3 percentage point smaller share of affected households' diets (about a $1 \%$ change over the pre-ban mean). The asset index falls by 0.032 for affected households; this represents about a 0.016 standard deviation change. While these household-level impacts may initially seem small, it is important to keep in mind that, similar to the design of the sibling-based regressions, the household regressions capture an intent-to-treat effect of the ban as we are using the age of children in the household as a proxy for being directly impacted by the ban. In the pre-ban period, about $10 \%$ of households have at least one working child under the age of 14 , suggesting that the implied treatment-on-the-treated could be up to a magnitude of order larger. Nonetheless we see these (precisely estimated) household results as primarily allowing us to rule out the possibility of welfare-improving effects of the 1986 ban. The lack of large changes in household consumption is in line with the model, which suggests that even when households send another child into the market, it is only to reach target subsistence. ${ }^{57}$

\footnotetext{
${ }^{55}$ The sample is defined as all households containing at least one child between the ages of 6 and 17.

${ }^{56}$ One issue that does concern us is the possibility that changes in child labor supply induced by the ban may affect household caloric intake and consumption patterns not only through its impact on household income but also through an increased demand for calories due to higher activity levels ( $\mathrm{Li}$ and Eli (2013)). The potential for such an increase in caloric intake due to increased activity suggests that the "net" effect on calories may be smaller than the effect due to reduced household income alone. However, a change in caloric needs for treated households would still be reflected in a rise in the staple share of calories - if the ban affects both income and consumption needs (through the effect on labor supply), the staple share will still be a reliable indicator of the net effect on household welfare (Jensen and Miller (2010)).

${ }^{57}$ Finding a zero net impact on household expenditure also gives us another way to infer changes in child productivity due to the ban. Our results indicate that the ban had virtually no effect on components of household income not derived from child labor, such as adult labor supply (discussed in more detail in the next section) or assets. However we do find a positive impact of the ban on child labor supply despite the net zero effect on household expenditure. Thus it appears that the increases child labor supply were entirely offset by decreases in child productivity, in line with the predictions of the model discussed in Section 3. Our back of the envelope calculations suggest that the implied decline in child productivity is about $8.7 \%$. (See the Online Appendix for more details on this calculation.) This figure is very similar in magnitude to our estimated impact of the ban on child wages of $7.8 \%$ (Table 5).
} 


\section{ROBUSTNESS CHECKS}

\subsection{Accounting for differential effects of sibling age structure and birth spacing over time}

Our sibling-based specification (2) compares children of the same age and therefore will not capture pre-existing secular trends in (own) age over time. To rule out the possibility that our results are contaminated by pre-existing trends in sibling age structure over time, we conduct several additional checks. First, in Appendix Table A.2 we see that when we allow for the effect of sibling age to vary by treatment status and survey round, the main sibling-based results very robust. ${ }^{58}$ In Appendix Table A.3, we falsely define sibling-based treatment as having a sibling aged 1-4, 5-9, or 14-17; the results of this placebo test indicate no significant false "effect" of the ban. This is as expected, since children ages 1-9 are highly unlikely to be working and thus their siblings are unlikely to be impacted by the ban through a drop in sibling wage income; those ages 14-17 are not targeted by the ban and thus their siblings should be similarly unaffected. The lack of placebo effects leads us to believe that our main estimates are not simply picking up the effect of having an older or younger sibling. Finally, in Appendix Table A.4 we show that our results are not simply due to differential trends by birth spacing over time. Column 1 restricts the sample to children whose nearest sibling is within 3 years of age to account for the possibility that treated children are more closely spaced than control children. Columns 2-4 adds controls for age gaps (on average between all children and between each child and her oldest and youngest sibling) and their interactions with the post-ban dummy to allow the effects of spacing to vary over time. The estimated impact of the ban generally remains similar in magnitude and statistical significance, though in column 2, we can see that when we allow the effect of the average age gap among all children in the household to vary over time, the estimated effect of the ban decreases in magnitude to 0.005 and is no longer statistically significant at conventional levels ( $\mathrm{p}$-value=0.145).

A related concern is that household structure may respond endogenously to the ban itself; to see whether this is the case, we regress household demographic variables on the household-level treatment variable as defined in the previous section. The results in Online Appendix Table A.5

\footnotetext{
${ }^{58}$ We control for sibling age linearly in two ways. First, we use the age of the "treatment-generating sibling", i.e. the closest to the 13/14 cutoff (using the age of younger siblings in the case of ties). Second we use the age of the nearest sibling in terms of the absolute difference in years between sibling age and own age.
} 
indicate that there is only one statistically significant endogenous response of household demographics to the ban (out of eight). Moreover, the effect is very small in magnitude; household size decreases by 0.029 members $(0.5 \%$ of the pre-ban mean). Thus we do not find evidence that the ban had any meaningful effect on household characteristics. ${ }^{59}$

Finally we test for secular time trends unrelated to the ban for treated and control children using only data from the post-ban era. In particular, we run a falsification test by estimating our main specifications but using 1987-8 as the "pre" and 1993-4 as the "post" period. The results (displayed in Appendix Table A.6) indicate that imposing a false ban date does not lead to significant "effects" of the ban for children ages 6-9 or ages 10-13. Hence, it appears that the policy change specific to 1986 is driving our results. ${ }^{60}$

\subsection{Accounting for differential effects of economic growth and state-level policies by age group}

To address the possible confounding effects of economic growth and/or state-level policies that may have affected younger children differently than older children, we perform several additional checks. First, we include interactions between time-varying state GDP measures and an indicator for having a sibling under 14. As columns 1 and 2 of Appendix Table A.7 indicate, allowing for these differential effects of economic growth on treated and control groups does not change our estimates of the impact of the ban. This provides further reassurance that economic growth in India over the 1983-1994 period - even to the extent it led to to differential trends in child employment for treated and control children - does not drive all of our estimated effects of the ban.

Next, we consider two specific policy changes that may be of particular importance when studying child employment. The first is changes to other labor laws. Importantly, other national

\footnotetext{
${ }^{59}$ Additionally, we find that the number of children in the household (or siblings) age 6-17 does not vary systematically with Under14XPost and that the probability of having a sibling under 14 (i.e. being "treated") does not change from the pre-ban to the post-ban period (results available upon request). We believe this helps us rule out the possibilities that the ban impacts selection into the sample generally as well as into the treatment group specifically.

${ }^{60} \mathrm{We}$ are reluctant to perform a similar falsification exercise using latter rounds of the NSS because there were substantive additions to the list of banned processes and occupations after 1994. As the ban applied to a wider set of activities over time, we might expect to find similar (though perhaps smaller) effects of the ban when using latter rounds. Nonetheless, when we re-run our specifications using the 1993-94 and 1999-2000 rounds we find coefficients that are very small and not statistically significant. Results available upon request.
} 
labor laws that would be pertinent to our case did not have age specific restrictions and were passed before $1983 .{ }^{61}$ In terms of state level labor policies, we examine changes to classifications as defined in Besley and Burgess (2004), which categorizes states as pro-worker, pro-employer or neutral. We find that only 3 out of 16 states in Besley-Burgess sample change classification between 1983-1994. When we restrict our sample to only those states without changes in these classifications, the estimated effects of the ban are very similar to the baseline estimates in Table 3; see columns 3 and 4 Appendix Table A.7.

Another policy that deserves further attention is the National Policy on Education that was amended and implemented in $1986 .^{62}$ This policy sought to improve educational achievement and enrollment for all ages, with a particular focus on primary education via "Operation Blackboard" (see Chin (2005) for more details).What implications does this policy have for our results? Any effect of primary school improvements targeted towards children up to age 9 (or secondary schooling improvements targeted to those over the age of 14) should lead us to find lower effects on our "treated" children (as children with siblings age 0-9 and above 14 are part of the "control" group); hence, to the extent that education policy was drawing very young or older children away from economic activity at the cost of increased labor supply of their siblings, our results can be interpreted as lower bounds for the true effect. To the extent that the "Operation Blackboard" interventions were targeted towards children in our "treatment-generating" age range of 10-13, our sibling-based estimates may confound the effect of these interventions as children may be drawn into the workforce in response to their 10-13 year old siblings spending more time in school. However we think is unlikely to contaminate our estimated effects, particularly for those in the very young age group (ages 6-9) as the within-family age-gradient in work probabilities is very steep; in other words, it is very rare that a child aged 6-9 is observed working when a 10-13 year old child in the same family is not working. Nonetheless, we show that our results are unchanged by restricting our sample to states less affected by "Operation Blackboard" in columns 5 and 6 of Appendix Table A.7.

\footnotetext{
${ }^{61}$ The Bonded Labour System (abolition) Act was passed in 1976, the Contract Labour (regulation and abolition) Act in 1970 and the Inter-State Migrant Workmen's Act in 1979.

${ }^{62}$ Our thanks to Anjini Kochar for pointing this out.
} 


\subsection{Additional checks and issues}

6.3.1. Effects on other ages. One of the main assumptions in the Basu (2005) and Basu and Van (1998) models is that adults supply labor inelastically. Hence, in response to lower child wages, we should not expect to see a response from adults (or in our framework, "young adults" who may be considered children by households but are classified as adults in the definitions set forth in the 1986 Act). In Online Appendix Table OA8, we show that this is precisely the case. Individuals above the age of 14 do not show any increases or decreases in labor supply in response to the ban. ${ }^{63}$

6.3.2. Measurement error and misreporting. With survey data, there is scope for measurement error in the reporting of child activities, especially with respect to child labor. In particular parents may underreport the labor of their children due to social or other types of pressure. Moreover it is possible that this underreporting increases differentially for children under the legal working age of 14 after the ban on child labor. Such underreporting should work against our results in that it would lead us to find lower reported levels of economic activity for children under the age of 14 after the ban is implemented. On the other hand, families may circumvent the law by misreporting age rather than work status. We investigate this concern in Figures OA9 and OA10 of the Online Appendix. If parents strategically report their children as being older in order to justify their employment we should see distinct jumps in reported age of children, particularly from age 13 to 14. However, we do not observe a larger jump in age reporting at 14 versus 13 after the ban is in place (neither in overall nor for children employed in banned occupations), thus it appears that the ban does not impact misreporting by parents. This does not rule out conventional (non-systematic) measurement error in reported age, which would serve to attenuate our estimates.

\section{CONCLUSION}

This paper is the first empirical investigation of the impact of India's most important legal action against child labor. While the Child Labor (Prohibition and Regulation) Act of 1986 was

\footnotetext{
${ }^{63}$ As in the household regressions, "treatment" is defined as having a child over the age of 10 but under the age of 14 in the household.
} 
created to prevent employers from employing children in certain occupations and increased regulation of child labor in non-family run businesses, the result of this ban appears to be a relative increase in economic activity for those under versus over the legal working age. Strikingly, we find relative increases in child work even in the very activities targeted by the law itself. While this might seem initially puzzling, anecdotal evidence and our empirical results suggest that the 1986 Act was imperfectly enforced and largely resulted in higher costs of employing children (and thus lower child wages) rather than the elimination of child labor in these activities as intended. We find that child wages decrease in response to the ban and affected families send out more children into the workforce. These results are consistent with a two sector model with some frictions on mobility across sectors where the ban is more stringently enforced in one sector than the other. Importantly, we also examine the overall welfare effects of the ban on households. Along various measures of household consumption and asset holdings we find that, if anything, the ban leads to decreases in household welfare.

This paper does not intend to suggest that all child labor bans are ineffective. In fact, well formulated and implemented bans could help in eliminating child labor $;{ }^{64}$ but as we do in this case, research would have to examine how a decrease in child labor affects child and household welfare (Baland and Robinson (2000); Beegle, Dehejia and Gatti (2009)). To echo the reasoning in Basu (2004): "Legal interventions, on the other hand, even when they are properly enforced so that they do diminish child labor, may or may not increase child welfare. This is one of the most important lessons that modern economics has taught us and is something that often eludes the policy maker."

In the particular case of the 1986 ban, this paper has shown that households are worse off along measures that reflect welfare. Not only is the ban ineffective in the short run (by not increasing household welfare and by not decreasing child labor), it can have perverse long run consequences by affecting human capital investments (Piza (2014)), asset accumulation and perhaps even fertility. Future research on child labor bans could focus on some of these long run effects. There are many options available to policy makers who wish to reduce the incidence of

\footnotetext{
${ }^{64}$ One way of achieving this in our context might be to increase fines and penalties to a point where employers no longer hire child labor or to increase enforcement.
} 
child labor (like cash transfers, increasing investments in and returns to education, etc). If anything, we think a discussion in policy circles about these alternatives should be heightened since it appears from our study that imperfectly implemented child labor bans alone can be ineffective. Our results highlight the importance of taking into account weak enforcement and behavior at the margin of subsistence when formulating important policies in developing countries. An approach that combines bans with other poverty alleviation strategies might be more effective in tackling the issue of child work.

\section{REFERENCES}

Bacolod, M. P. and P. Ranjan (2008). Why children work, attend school, or stay idle: the roles of ability and household wealth. Economic Development and Cultural Change 56(4), 791-828.

Baland, J.-M. and J. A. Robinson (2000). Is child labor inefficient? Journal of Political Economy 108(4), 663-679.

Bargain, O., S. K. Bhaumik, M. Chakrabarty, and Z. Zhao (2009). Earnings differences between chinese and indian wage earners, 1987-2004. Review of Income and Wealth 55(s1), 562-587.

Basu, K. (1999). Child labor: cause, consequence, and cure, with remarks on international labor standards. Journal of Economic Literature 37(3), 1083-1119.

Basu, K. (2005). Child labor and the law: Notes on possible pathologies. Economics Letters 87(2), 169-174.

Basu, K. and P. H. Van (1998). The economics of child labor. American Economic Review, 412427.

Beegle, K., R. Dehejia, and R. Gatti (2009). Why should we care about child labor? the education, labor market, and health consequences of child labor. Journal of Human Resources 44(4), 871889.

Besley, T. and R. Burgess (2004). Can labor regulation hinder economic performance? evidence from india. The Quarterly Journal of Economics 119(1), 91-134.

Bhalotra, S. (2007). Is child work necessary? Oxford Bulletin of Economics and Statistics 69(1), $29-55$.

Bhalotra, S. and C. Heady (2003). Child farm labor: The wealth paradox. The World Bank Economic Review 17(2), 197-227.

Biggeri, M., L. Guarcello, S. Lyon, and F. C. Rosati (2003). The puzzle of "idle" children: Neither in school nor performing economic activity: Evidence from six countries. Understanding Children's Work Project draft working paper, August.

Boockmann, B. (2010). The effect of ilo minimum age conventions on child labor and school attendance: Evidence from aggregate and individual-level data. World Development 38(5), 679692.

Bugni, F. A. (2012). Child labor legislation: Effective, benign, both or neither? Cliometrica 6(3), 223-248.

Cameron, A. C., J. B. Gelbach, and D. L. Miller (2008). Bootstrap-based improvements for inference with clustered errors. The Review of Economics and Statistics 90(3), 414-427.

Chin, A. (2005). Can redistributing teachers across schools raise educational attainment? evidence from operation blackboard in india. Journal of Development Economics 78, 384-405. 
Commons, J. R. (1924). Law and economics. Yale Law Journal 34, 371.

Das, R. K. (1933). Child labour in india: I. International Labour Review 28(796).

Doepke, M. and F. Zilibotti (2005). The macroeconomics of child labor regulation. American Economic Review 95(5), 1492-1524.

Doran, K. (2013). How does child labor affect the demand for adult labor? evidence from rural mexico. Journal of Human Resources 48(3), 703-735.

Dutta, P. V. (2006). Returns to education: New evidence for india, 1983-1999. Education Economics 14(4), 431-451.

Edmonds, E. V. (2005). Does child labor decline with improving economic status? Journal of Human Resources 40(1), 77-99.

Edmonds, E. V. (2007). Child labor. Handbook of Development Economics 4, 3607-3709.

Edmonds, E. V. and N. Pavcnik (2005a). Child labor in the global economy. The Journal of Economic Perspectives 19(1), 199-220.

Edmonds, E. V. and N. Pavcnik (2005b). The effect of trade liberalization on child labor. Journal of International Economics 65(2), 401-419.

Edmonds, E. V., N. Pavcnik, and P. Topalova (2010). Trade adjustment and human capital investments: Evidence from indian tariff reform. American Economic Journal: Applied Economics 2(4), 42-75.

Edmonds, E. V. and M. Shrestha (2012a). Impact of minimum age of employment regulation on child labor and schooling. IZA Journal of Labor Policy (14), 1-28.

Edmonds, E. V. and M. Shrestha (2012b). Impact of minimum age of employment regulation on child labor and schooling: Evidence from unicef mics countries. NBER Working Paper Series (18623).

Gopalan, C., B. Rama Sastri, and S. Balasubramanian (1980). Nutritive Values of Indian Foods (3rd edition). Hyderabad: National Institute of Nutrition, Indian Council of Medical Research.

Gordon, R. and W. Li (2009). Tax structures in developing countries: Many puzzles and a possible explanation. Journal of Public Economics 93(7), 855-866.

Government of Gujarat (2004). Performance review chapter iii. Civil Audit Report.

Heath, R. and A. M. Mobarak (2014). Manufacturing growth and the lives of bangladeshi women. NBER Working Paper Series (18623).

Human Rights Watch (2003). Small change: Bonded child labor in india's silk industry. Human Rights Watch Special Report.

International Labour Organization (2013). Marking progress against child labour - global estimates and trends 2000-2012. ILO Report.

Jayachandran, S. (2006). Selling labor low: Wage responses to productivity shocks in developing countries. Journal of Political Economy 114(3), 538-575.

Jensen, R. T. and N. H. Miller (2010). A revealed preference approach to measuring hunger and undernutritiono. NBER Working Paper (16555).

Li, N. and S. Eli (2013). Can caloric needs explain three food consumption puzzles? evidence from india. Working Paper.

Lleras-Muney, A. (2002). Were compulsory attendance and child labor laws effective? an analysis from 1915 to 1939. The Journal of Law \& Economics 45, 401-691.

Manacorda, M. (2006). Child labor and the labor supply of other household members: Evidence from 1920 america. The American Economic Review 96(5), 1788-1801.

Moehling, C. M. (1999). State child labor laws and the decline of child labor. Explorations in Economic History 36(1), 72-106. 
Munshi, K. and M. Rosenzweig (2006). Traditional institutions meet the modern world: Caste, gender, and schooling choice in a globalizing economy. American Economic Review 96(4), $1225-1252$.

Piza, C. (2014). Long-term efeccts of child labour bans on adult outcomes: Evidence from brazil. Working Paper.

Ramanathan, U. (2009). Evolution of the law on child labor in india. The World of Child Labor. An Historical and Regional Survey.

Skoufias, E., S. W. Parker, J. R. Behrman, and C. Pessino (2001). Conditional cash transfers and their impact on child work and schooling: Evidence from the progresa program in mexico [with comments]. Economia 2(1), 45-96.

Stigler, G. J. (1992). Law or economics? Journal of Law and Economics 35(2), 455-468.

Sunstein, C. R. (1994). Political equality and unintended consequences. Columbia Law Review 94(4), 1390-1414.

Thirumurthy, H., J. Zivin, and M. Goldstein (2007). Aids treatment and intrahousehold resource allocations: Children's nutrition and schooling in kenya. Center for Global Development Working Paper (105).

Webb, M. D. (2013). Reworking wild bootstrap based inference for clustered errors. Technical report, Queen's Economics Department Working Paper.

Weiner, M. (1991). The child and the state in India: Child labor and education policy in comparative perspective. Princeton University Press. 
TABles

TABLE 1A. Summary statistics: Means of child variables by sibling treatment status and period

\begin{tabular}{lcccccc}
\hline \hline & & 1983 & \multicolumn{3}{c}{$1987-8,1993-4$} \\
\hline & All & Control & Treated & All & Control & Treated \\
& $(1)$ & $(2)$ & $(3)$ & $(4)$ & $(5)$ & $(6)$ \\
\hline Family Size & 6.94 & 6.64 & 7.00 & 6.74 & 6.57 & 6.77 \\
Head Age & 44.8 & 43.4 & 45.0 & 44.6 & 43.4 & 44.9 \\
Head Is Male & 0.924 & 0.932 & 0.923 & 0.924 & 0.928 & 0.923 \\
Head Has No Education & 0.511 & 0.502 & 0.512 & 0.428 & 0.442 & 0.425 \\
Head Has at least Some Primary Eduction & 0.264 & 0.253 & 0.267 & 0.271 & 0.264 & 0.273 \\
Head Has Middle Eduction & 0.103 & 0.107 & 0.102 & 0.120 & 0.114 & 0.121 \\
Head Has Secondary Education or More & 0.122 & 0.138 & 0.119 & 0.181 & 0.180 & 0.181 \\
Hindu Household & 0.776 & 0.782 & 0.774 & 0.767 & 0.770 & 0.767 \\
Urban Area & 0.318 & 0.321 & 0.317 & 0.328 & 0.327 & 0.329 \\
Real Monthly Expenditure per capita & 131.9 & 136.8 & 130.9 & 137.4 & 134.9 & 138.0 \\
Food Expenditure per capita & 69.2 & 69.8 & 69.1 & 81.7 & 80.2 & 82.0 \\
Calories per capita & 2159.9 & 2130.8 & 2165.8 & 2173.6 & 2115.8 & 2185.8 \\
Staple Share of Calories & 0.713 & 0.708 & 0.713 & 0.680 & 0.676 & 0.681 \\
Asset Index & -0.715 & -0.707 & -0.716 & 0.137 & 0.106 & 0.144 \\
Principal Industry is Banned & 0.114 & 0.121 & 0.113 & 0.120 & 0.122 & 0.120 \\
Number of observations & 50232 & 8458 & 41774 & 92423 & 16491 & 77945 \\
\hline \hline
\end{tabular}

"Treated" households are defined as having at least 1 child aged 10-13. Real values (expressed in 1982 rupees) are nominal values deflated by the average wholesale price index reported by the Government of India for the respective year. Sample consists of all households with at least one child aged 6-13 who also has at least one sibling in the age range 6-17. 
TABLE 1B. Summary statistics: Means of child variables by sibling treatment status and period

\begin{tabular}{|c|c|c|c|c|c|c|}
\hline & \multicolumn{6}{|c|}{ Ages 10-13 } \\
\hline & \multicolumn{3}{|c|}{1983} & \multicolumn{3}{|c|}{$1987-8,1993-4$} \\
\hline & $\begin{array}{l}\text { All } \\
(1)\end{array}$ & $\begin{array}{l}\text { Control } \\
\text { (2) }\end{array}$ & $\begin{array}{l}\text { Treated } \\
\text { (3) }\end{array}$ & $\begin{array}{l}\text { All } \\
(4)\end{array}$ & $\begin{array}{l}\text { Control } \\
(5)\end{array}$ & $\begin{array}{c}\text { Treated } \\
\text { (6) }\end{array}$ \\
\hline \multicolumn{7}{|l|}{ Panel A: All Children } \\
\hline Male & 0.527 & 0.533 & 0.522 & 0.533 & 0.542 & 0.524 \\
\hline Has a working sibling under age 14 & 0.064 & 0.014 & 0.116 & 0.036 & 0.005 & 0.068 \\
\hline (Principally) Attending School & 0.607 & 0.587 & 0.630 & 0.734 & 0.723 & 0.746 \\
\hline (Principally Engaged in) Any Economic Activity & 0.116 & 0.126 & 0.105 & 0.067 & 0.071 & 0.062 \\
\hline (Principally Performing) Unpaid Household Services & 0.123 & 0.129 & 0.116 & 0.066 & 0.070 & 0.062 \\
\hline Days Spent in Economic Activity in Past Week & 0.770 & 0.835 & 0.699 & 0.466 & 0.494 & 0.437 \\
\hline Days Spent in School in Past Week & 4.155 & 4.012 & 4.308 & 5.011 & 4.942 & 5.085 \\
\hline Days Spent in Unpaid Household Services in Past Week & 0.900 & 0.948 & 0.850 & 0.482 & 0.515 & 0.447 \\
\hline Number of observations & 61480 & 31816 & 29664 & 114145 & 58582 & 55563 \\
\hline \multicolumn{7}{|l|}{ Panel B: Children Principally Engaged in Economic Activities } \\
\hline Engaged in Unpaid Economic Activity & 0.660 & 0.665 & 0.653 & 0.628 & 0.632 & 0.623 \\
\hline Engaged in Paid Employment & 0.340 & 0.335 & 0.347 & 0.372 & 0.368 & 0.377 \\
\hline Employment in banned industry & 0.081 & 0.081 & 0.080 & 0.097 & 0.094 & 0.101 \\
\hline Days Spent in Any Economic Activity in Past Week & 6.099 & 6.119 & 6.072 & 6.276 & 6.264 & 6.291 \\
\hline Days Spent in School in Past Week & 0.017 & 0.012 & 0.024 & 0.035 & 0.046 & 0.022 \\
\hline Days Spent in Unpaid Household Services in Past Week & 0.459 & 0.460 & 0.457 & 0.273 & 0.273 & 0.273 \\
\hline Real Daily Wages (1982 Rupees) & 3.714 & 3.819 & 3.581 & 2.832 & 2.847 & 2.814 \\
\hline Number of observations & 7145 & 4022 & 3123 & 7617 & 4172 & 3445 \\
\hline
\end{tabular}

"Treated" children are defined as having at least 1 sibling aged 10-13. Real values (expressed in 1982 rupees) are nominal values deflated by the average wholesale price index reported by the Government of India for the respective year. Sample consists of all individuals related to the household head with at least 1 other (related) household member age 6-17. 
TABLE 2. Simple Estimates of the Effects of the Ban on Child Time Allocation

\begin{tabular}{lcccccccc}
\hline \hline & $\begin{array}{c}\text { Any } \\
\text { Economic } \\
\text { Activity } \\
(1)\end{array}$ & $\begin{array}{c}\text { Any } \\
\text { Economic } \\
\text { Activity } \\
(2)\end{array}$ & $\begin{array}{c}\text { Employment } \\
\text { in Banned } \\
\text { Occ. } \\
(3)\end{array}$ & $\begin{array}{c}\text { Employment } \\
\text { in Non-Banned } \\
\text { Occ. } \\
(4)\end{array}$ & $\begin{array}{c}\text { Unpaid } \\
\text { Economic } \\
\text { Activity } \\
(5)\end{array}$ & $\begin{array}{c}\text { Paid } \\
\text { Employment } \\
(6)\end{array}$ & $\begin{array}{c}\text { Attending } \\
\text { School } \\
(7)\end{array}$ & $\begin{array}{c}\text { Unpaid } \\
\text { Household } \\
\text { Services } \\
(8)\end{array}$ \\
\hline Under14XPost & 0.024 & $0.026^{* * *}$ & $0.004^{* * *}$ & $0.023^{* * *}$ & $0.007^{*}$ & $0.019^{* * *}$ & 0.008 & $-0.009^{* *}$ \\
& $(0.040)$ & $(0.005)$ & $(0.001)$ & $(0.005)$ & $(0.003)$ & $(0.002)$ & $(0.007)$ & $(0.004)$ \\
\hline Pre-Ban Mean & & & & & & & & \\
of Dep. Var. & 0.118 & 0.118 & 0.009 & 0.108 & 0.077 & 0.041 & 0.604 & 0.124 \\
Observations & 327,233 & 327,233 & 326,768 & 326,768 & 327,233 & 327,233 & 327,233 & 327,233 \\
R-squared & 0.055 & 0.182 & 0.030 & 0.162 & 0.093 & 0.099 & 0.303 & 0.211 \\
Controls? & No & Yes & Yes & Yes & Yes & Yes & Yes & Yes \\
\hline \hline
\end{tabular}

*** $\mathrm{p}<0.01, * * \mathrm{p}<0.05, * \mathrm{p}<0.1$ "Under14" is a dummy variable that takes the value of 1 if the child is under 14 years of age. Column 1 includes only a Post-ban dummy, the "Under14" dummy, and an interaction between "Under14" and Post. Controls: gender, gender of household head, age of household head, urban status, number of adult females, number of male children, number of female children, number of children under 5, number of children ages 6-9 as well as the following fixed effects: age, family size, household head's education level, religion, survey round, survey quarter, state. Sample consists of all individuals related to the household head aged 10-17. Standard errors are clustered by age-survey round. Pre-Ban mean is for children under the age of 14 only. Columns 4 and 5 : Smaller sample sizes are due to missing NIC codes. Employment in non-banned occupations includes all unpaid economic activity within the household and paid employment in non-banned occupations. 
TABLE 3. Sibling-based Estimates of the Effects of the Ban on Child Time Allocation

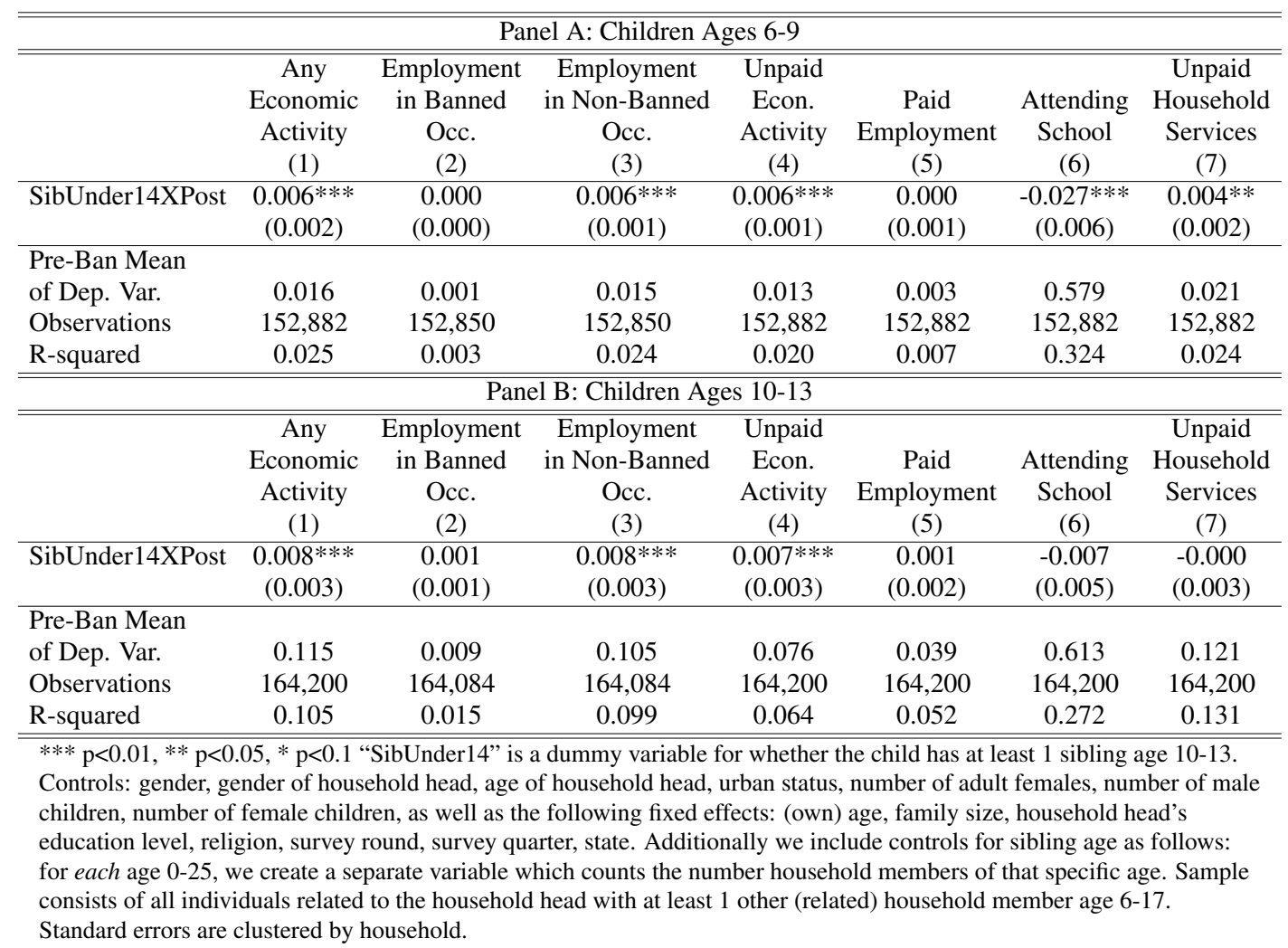


TABLE 4. Geographical Heterogeneity

\begin{tabular}{|c|c|c|c|c|}
\hline & \multicolumn{4}{|c|}{ Dependent Variable: Any Economic Activity } \\
\hline & \multicolumn{2}{|c|}{$\begin{array}{c}\text { Importance of } \\
\text { Banned Industries }\end{array}$} & \multicolumn{2}{|c|}{$\begin{array}{l}\text { Probability } \\
\text { of Detection }\end{array}$} \\
\hline & $\begin{array}{l}\text { Simple } \\
\text { Estimate } \\
\text { (1) }\end{array}$ & $\begin{array}{l}\text { Sibling-based } \\
\text { Estimate } \\
\text { (2) }\end{array}$ & $\begin{array}{l}\text { Simple } \\
\text { Estimate } \\
\text { (3) }\end{array}$ & $\begin{array}{l}\text { Sibling-based } \\
\text { Estimate } \\
\text { (4) }\end{array}$ \\
\hline AboveMedianXUnder14XPost & $\begin{array}{l}0.008 \\
(0.009)\end{array}$ & $\begin{array}{l}0.015^{* *} \\
(0.006)\end{array}$ & $\begin{array}{l}0.015^{*} \\
(0.008)\end{array}$ & $\begin{array}{l}0.014 * * \\
(0.006)\end{array}$ \\
\hline Under14XPost & $\begin{array}{c}0.023 * * * \\
(0.007)\end{array}$ & $\begin{array}{c}0.002 \\
(0.005)\end{array}$ & $\begin{array}{c}0.017 * * * \\
(0.005)\end{array}$ & $\begin{array}{c}0.004 \\
(0.005)\end{array}$ \\
\hline Age ( & $10-17$ & $10-13$ & $10-17$ & $10-$ \\
\hline Obse & 327,233 & 164,200 & 298,357 & 150,021 \\
\hline R-squared & 0.183 & 0.105 & 0.184 & 0.106 \\
\hline $\begin{array}{l}* * * \text { p }<0.01, * * \text { p }<0.05, * \mathrm{p}<0.1 . \\
\text { proportion of households in the st } \\
\text { (3) and (4): The probability of ins } \\
\text { inspections at the state-level durin } \\
\text { www.indiastat.com), scaled by th } \\
\text { would be banned under the } 1986 \\
\text { following states/UTs: Himachal } \mathrm{F} \\
\text { Islands, Arunachal Pradesh, Delh } \\
\text { original overall and sibling sampl } \\
\text { median) and low (below median) } \\
\text { resulting dummy variables are us } \\
\text { gender, gender of household head } \\
\text { females, number of male children } \\
\text { number of children ages } 6-9 \text { as w } \\
\text { head's education level, religion, s } \\
\text { include interactions between all c } \\
\text { measure of heterogeneity. Standa } \\
\text { (3): "Under14" is a dummy varial } \\
\text { age. Sample consists of all indivi } \\
\text { and (4): "Under14" is a dummy v } \\
\text { sibling age } 10-13 \text {. In addition to t } \\
\text { as follows: for each age } 0-25 \text {, we }\end{array}$ & $\begin{array}{l}\text { Note that } \\
\text { sh, Mani } \\
\text { kshadwe } \\
\text { espectivel } \\
\text { ortance/pr } \\
\text { create th } \\
\text { of house } \\
\text { mber of fe } \\
\text { s the follo } \\
\text { y round, s } \\
\text { ol variabl } \\
\text { rors are c } \\
\text { hat takes } \\
\text { related t } \\
\text { ple that ta } \\
\text { ontrols all }\end{array}$ & $\begin{array}{l}7-2005 \text { (as rep } \\
\text { Iren working in } \\
\text { spection data is } \\
\text { Nagaland, Tri } \\
\text { and Mizoram ( } \\
\text { We then separ } \\
\text { ability states ba } \\
\text { levant interact } \\
\text { d head, urban } \\
\text { le children, nu } \\
\text { ag fixed effects } \\
\text { ey quarter, stat } \\
\text { including "Und } \\
\text { tered by at the } \\
\text { value of } 1 \text { if th } \\
\text { ee household he } \\
\text { the value of } 1 \\
\text { ly listed, we in } \\
\text { variable which }\end{array}$ & $\begin{array}{l}\text { ot availab } \\
\text { ura, Anda } \\
\text { bout } 8.8 \% \\
\text { e states in } \\
\text { ed on thes } \\
\text { n terms a } \\
\text { atus, num } \\
\text { ber of chi } \\
\text { age, famil regre } \\
\text { ate-level. } \\
\text { child is u } \\
\text { d aged } 10 \\
\text { the child } \\
\text { ude contr } \\
\text { counts the }\end{array}$ & $\begin{array}{l}\text { as the } 1983 \\
86 \text { ). Columns } \\
\text { the number of } \\
\text { tat, } \\
\text { ations that } \\
\text { or the } \\
\text { \& Nicobar } \\
8.6 \% \text { of the } \\
\text { igh (above } \\
\text { easures; the } \\
\text { e. Controls: } \\
\text { of adult } \\
\text { en under } 5 \text {, } \\
\text { ze, household } \\
\text { ons also } \\
\text { st") and the } \\
\text { umns (1) and } \\
\text { 14 years of } \\
\text { Columns (2) } \\
\text { at least } 1 \\
\text { for sibling age } \\
\text { mber } \\
\text { ed to the }\end{array}$ \\
\hline
\end{tabular}


TABLE 5. Effects of the Ban on Child Wages

\begin{tabular}{lcccccc}
\hline \hline \multicolumn{7}{c}{ Dependent Variable: Log(Real Wage) } \\
\hline & Ages 6-21 & Ages 6-21 & Ages 7-20 & Ages 8-19 & Ages 9-18 & Ages 10-17 \\
& $(1)$ & $(2)$ & $(3)$ & $(4)$ & $(5)$ & $(6)$ \\
\hline Under14XPost & -0.100 & $-0.078^{* * *}$ & $-0.076^{* * *}$ & $-0.070^{* * *}$ & $-0.065^{* *}$ & -0.043 \\
& $(0.085)$ & $(0.023)$ & $(0.024)$ & $(0.025)$ & $(0.027)$ & $(0.026)$ \\
\hline Observations & 33,731 & 33,731 & 30,566 & 23,648 & 20,696 & 14,848 \\
R-squared & 0.128 & 0.392 & 0.378 & 0.357 & 0.343 & 0.313 \\
\hline \hline Controls? & No & Yes & Yes & Yes & Yes & Yes \\
\hline \hline *** p<0.01, ** p<0.05, * p<0.1 Each column uses individuals related to the household head in the \\
specified age range. "Under14" is a dummy variable that takes the value of 1 if the child is under 14 \\
years of age. Real values (expressed in 1982 rupees) are nominal values deflated by the average \\
wholesale price index reported by the Government of India for the respective year. Wages are \\
trimmed of the top and bottom 1\% of values within each round. Controls: gender, gender of \\
household head, age of household head, urban status, number of adult females, number of male \\
children, number of female children, number of children under 5, number of children ages 6-9 as \\
well as the following fixed effects: age, family size, household head's education level, religion, \\
survey round, survey quarter, state, industry. Standard errors are clustered by age-survey round.
\end{tabular}

TABLE 6. Effect of the Ban on Household Outcomes

\begin{tabular}{|c|c|c|c|c|c|}
\hline & $\begin{array}{c}\text { Log Total } \\
\text { Expenditure } \\
\text { Per Capita } \\
\text { (1) }\end{array}$ & $\begin{array}{c}\text { Log Food } \\
\text { Expenditure } \\
\text { Per Capita } \\
\text { (2) }\end{array}$ & $\begin{array}{c}\text { Log Daily } \\
\text { Calories } \\
\text { Per Capita } \\
\text { (3) }\end{array}$ & $\begin{array}{c}\text { (1-Staple } \\
\text { Share of } \\
\text { Calories) } \\
(4)\end{array}$ & $\begin{array}{c}\text { Asset } \\
\text { Index } \\
(5)\end{array}$ \\
\hline $\begin{array}{l}\text { ChildUnder14 } \\
\text { XPost }\end{array}$ & $\begin{array}{l}-0.005 \\
(0.004)\end{array}$ & $\begin{array}{l}-0.005 \\
(0.003)\end{array}$ & $\begin{array}{c}0.000 \\
(0.003)\end{array}$ & $\begin{array}{c}-0.003 * * * \\
(0.001)\end{array}$ & $\begin{array}{l}-0.034^{* *} \\
(0.014)\end{array}$ \\
\hline $\begin{array}{l}\text { Pre-Ban Mean } \\
\text { of Dep. Var. } \\
\text { Observations } \\
\text { R-squared }\end{array}$ & $\begin{array}{c}\text { N/A } \\
222,604 \\
0.382\end{array}$ & $\begin{array}{c}\text { N/A } \\
220,358 \\
0.364\end{array}$ & $\begin{array}{c}\text { N/A } \\
220,362 \\
0.185\end{array}$ & $\begin{array}{c}0.292 \\
220,357 \\
0.498\end{array}$ & $\begin{array}{c}-0.732 \\
220,542 \\
0.548\end{array}$ \\
\hline \multicolumn{6}{|c|}{$\begin{array}{l}* * * \mathrm{p}<0.01, * * \mathrm{p}<0.05, * \mathrm{p}<0.1 \text {. "ChildUnder14" is a dummy variable that takes the } \\
\text { value of } 1 \text { if there is at least one child age } 10-13 \text { in the household. Sample consists of } \\
\text { households with at least one household member age } 6-17 \text {, trimmed of the top and } \\
\text { bottom } 1 \% \text { of values of the dependent variable within each round. Robust standard } \\
\text { errors reported. Controls: gender of household head, age of household head, urban } \\
\text { status, number of adult females, number of male children, number of female children, } \\
\text { number of children under } 5 \text {, number of children ages } 6-9 \text { as well as the following fixed } \\
\text { effects: family size, household head's education level, religion, survey round, survey } \\
\text { quarter, state. Additionally we include controls for sibling age as follows: for each age } \\
0-25 \text {, we create a separate variable which counts the number household members of } \\
\text { that specific age. }\end{array}$} \\
\hline
\end{tabular}


Appendix A. Appendix Tables

TABLE A.1. Alternate Sibling Samples (Ages: 10-13)

\begin{tabular}{|c|c|c|c|c|c|c|}
\hline \multicolumn{7}{|c|}{ Dependent Variable: Any Economic Activity } \\
\hline & $\begin{array}{c}\text { Baseline } \\
\text { Specification } \\
\text { (1) }\end{array}$ & $\begin{array}{l}\text { All Empl. } \\
\text { and Cons. } \\
\text { Rounds } \\
\text { (2) }\end{array}$ & $\begin{array}{c}\text { Round } 42 \\
\text { (July 1986- } \\
\text { June 1987) } \\
\text { (3) }\end{array}$ & $\begin{array}{l}\text { Excluding Children } \\
\text { whose "Treatment- } \\
\text { Generating" } \\
\text { Sibling is Younger } \\
\text { (4) }\end{array}$ & $\begin{array}{c}\text { Only } \\
\text { Children with } \\
\text { Siblings Ages 8-15 } \\
\text { (5) }\end{array}$ & $\begin{array}{c}\text { Only } \\
\text { Unmarried Children } \\
\text { of HH Head } \\
(6)\end{array}$ \\
\hline SibUnder14 & $0.008 * * *$ & $0.010 * * *$ & 0.001 & $0.022 * * *$ & $0.007 * *$ & $0.007 * *$ \\
\hline Xpost & $(0.003)$ & $(0.003)$ & $(0.005)$ & $(0.003)$ & $(0.003)$ & $(0.003)$ \\
\hline Survey Years & $1983,1987-8$ & All Rds. & July 1986 & $1983,1987-8$ & $1983,1987-8$ & $1983,1987-8$ \\
\hline Included & $1993-4$ & 1983-1994 & - June 1987 & 1993-4 & $1993-4$ & $1993-4$ \\
\hline $\begin{array}{l}\text { Pre-Ban Mean } \\
\text { of Dep. Var. }\end{array}$ & 0.115 & 0.115 & 0.058 & 0.103 & 0.112 & 0.113 \\
\hline Observations & 164,200 & 212,715 & 44,910 & 122,034 & 144,340 & 137,633 \\
\hline R-squared & 0.106 & 0.110 & 0.040 & 0.098 & 0.106 & 0.107 \\
\hline
\end{tabular}

*** $\mathrm{p}<0.01, * * \mathrm{p}<0.05, * \mathrm{p}<0.1$ Cols (1),(4)-(6): Sample period includes Rounds 38, 43 and 50 (1983, 1987-8, 1993-4). Col (2): Employment and consumption rounds of the NSS: 38, 43, 45, 46, 47, 48, 49, 50 (1983-1994). Col (3) uses Round 42 (1987-8) only.

$\mathrm{Col}(4)$ : Note that the definition of Economic Activity differs from all other columns; defined only for children who do not attend school (see Section 5.1 and Online Appendix for more details). Col(4): Sample excludes all children who are older than their sibling aged 10-13. Col (5): Sample is further restricted to only children with siblings ages 8-15. Col (6): Sample includes only unmarried children of the household head (restriction applies to siblings as well). For all columns: SEs clustered by HH. Controls: gender, gender and age of $\mathrm{HH}$; urban status; counts of adult females, male children, female children, children under 5, children ages 6-9; and the following fixed effects: age, family size, HH head's educ., relig., survey round, survey quarter, state. Additionally for each age 0-25 we include a separate variable which counts the no. household members of that specific age. 
TABLE A.2. Allowing the Effect of Sibling Age to Differ over Time and by Treatment Status

\begin{tabular}{|c|c|c|c|c|c|c|}
\hline & \multicolumn{6}{|c|}{ Dependent Variable: Any Economic Activity } \\
\hline & \multicolumn{3}{|c|}{ Using Age of Sibling Closest to $13 / 14$ Cutoff } & \multicolumn{3}{|c|}{ Using Age of Nearest Sibling } \\
\hline & \multicolumn{3}{|c|}{$\begin{array}{r}\text { Effect of Sibling Age Is Allowed to Differ... } \\
\text {...by Treatment }\end{array}$} & \multicolumn{3}{|c|}{ Effect of Sibling Age Is Allowed to Differ... } \\
\hline & ...in Each & ...by Treatment & Status and & ...in Each & ...by Treatment & Status and \\
\hline & $\begin{array}{l}\text { Survey Round } \\
\text { (1) }\end{array}$ & $\begin{array}{l}\text { Status } \\
(2)\end{array}$ & $\begin{array}{l}\text { Survey Round } \\
\text { (3) }\end{array}$ & $\begin{array}{l}\text { Survey Round } \\
\text { (4) }\end{array}$ & $\begin{array}{l}\text { Status } \\
(5)\end{array}$ & $\begin{array}{l}\text { Survey Round } \\
\text { (6) }\end{array}$ \\
\hline SibUnder14 & $0.008 * * *$ & $0.009 * * *$ & $0.008 * * *$ & $0.008 * * *$ & $0.008 * * *$ & $0.008 * * *$ \\
\hline & $(0.003)$ & $(0.003)$ & $(0.003)$ & $(0.003)$ & $(0.003)$ & $(0$. \\
\hline Obser & 162,883 & 174,970 & 162,883 & 164,200 & 164,200 & 164,200 \\
\hline R-squared & 0.105 & 0.104 & 0.105 & 0.105 & 0.105 & 0.105 \\
\hline
\end{tabular}

*** $\mathrm{p}<0.01, * * \mathrm{p}<0.05, * \mathrm{p}<0.1$. "SibUnder14"=dummy variable for whether the child has at least one sibling in age 10-13. Cols (1)-(3): Controls include age of sibling closest to the 13/14 cutoff (using younger siblings' ages in the case of a tie) as well as interactions with treatment status and/or survey round dummies (as indicated above each column). Cols (4)-(6):

Controls include age of sibling closest to own age as well as interactions with treatment status and/or survey round dummies (as indicated above each column). Sample: all aged 10-13 related to the HH head with at least 1 (related) HH member aged 6-17. Controls for all columns: gender and age of $\mathrm{HH}$; urban status; counts of adult females, male children, female children, children under 5, children ages 6-9, and the no. of household members of each age 0-25; and the following fixed effects: family size, HH head's educ., relig., survey round, survey quarter, state. SE are clustered by household. 
TABLE A.3. Redefining Work-Eligible Age

\begin{tabular}{lcccc}
\hline \hline & \multicolumn{3}{c}{ Dependent Variable: Any Economic Activity } \\
\hline & Baseline & \multicolumn{3}{c}{ Placebo Tests } \\
& $\begin{array}{c}\text { Ages 10-13 } \\
(1)\end{array}$ & $\begin{array}{c}\text { Ages 1-4 } \\
(2)\end{array}$ & $\begin{array}{c}\text { Ages 5-9 } \\
\text { Agned"= }\end{array}$ & $\begin{array}{c}\text { Ages 14-17 } \\
(3)\end{array}$ \\
\hline SibUnder14XPost & $0.008^{* * *}$ & 0.002 & -0.006 & 0.004 \\
& $(0.003)$ & $(0.004)$ & $(0.005)$ & $(0.004)$ \\
\hline Pre-Ban Mean of Dep. Var. & 0.115 & 0.125 & 0.125 & 0.125 \\
Observations & 164,200 & 78,973 & 78,973 & 78,973 \\
R-squared & 0.105 & 0.103 & 0.103 & 0.103 \\
\hline *** p<0.01, ** p<0.05, * p<0.1. "SibUnder14"=dummy variable for whether the child has \\
at least one sibling in specified age range. Sample for Col (1): all aged 10-13 related to the \\
HH head with at least one (related) HH member aged 6-17. Sample for Cols (2)-(4): all \\
aged 10-13 related to the HH head with at least one (related) HH member aged 6-17, \\
excluding all "treated" children with siblings ages 10-13. Controls (all columns): gender \\
and age of HH; urban status; counts of adult females, male children, female children, \\
children under 5, children ages 6-9, and the no. of household members of each age 0-25 as \\
separate variables; and the following fixed effects: family size, HH head's educ., relig., \\
survey round, survey quarter, state. SE are clustered by household.
\end{tabular}

TABLE A.4. Accounting for Differential Birth Spacing

\begin{tabular}{lcccc}
\hline \hline \multicolumn{5}{c}{ Dependent Variable: Any Economic Activity } \\
\hline & Restricted Sample: & Average Sibling & Age Gap to & Age Gap to \\
& Only Those with a & Age Gap and & Oldest Sibling & Youngest Sibling \\
& Sibling within & Interaction & and Interaction & and Interaction \\
& 3 Yrs. of Own Age & with Post & with Post & with Post \\
& $(1)$ & $(2)$ & $(3)$ & $(4)$ \\
\hline SibUnder14XPost & $0.006^{*}$ & 0.005 & $0.007^{* *}$ & $0.008^{* * *}$ \\
& $(0.003)$ & $(0.003)$ & $(0.003)$ & $(0.003)$ \\
\hline Observations & 136,944 & 164,200 & 164,200 & 164,200 \\
R-squared & 0.104 & 0.105 & 0.105 & 0.105 \\
\hline \hline
\end{tabular}

*** $\mathrm{p}<0.01, * * \mathrm{p}<0.05, * \mathrm{p}<0.1$. "SibUnder14"=dummy variable for whether the child has at least one sibling in age 10-13. Col (1): Sample is further restricted to children with at least one sibling within 3 years of own age. Cols (2)-(4) Age Gap is calculated as the absolute number of years between self and all/oldest/youngest sibling. Sample (all columns except (1)): all aged 10-13 related to the HH head with at least one (related) HH member aged 6-17. Controls (all columns): gender and age of HH; urban status; counts of adult females, male children, female children, children under 5, children ages 6-9, and the no. of household members of each age 0-25 (as separate variables); and the following fixed effects: family size, HH head's educ., relig., survey round, survey quarter, state. SE are clustered by household. 
TABLE A.5. Falsification Test: Effect of the Ban on Demographics

\begin{tabular}{|c|c|c|c|c|c|c|c|c|}
\hline & $\begin{array}{l}\text { Child is } \\
\text { Male } \\
\text { (1) }\end{array}$ & $\begin{array}{l}\mathrm{HH} \\
\text { Size } \\
(2)\end{array}$ & $\begin{array}{l}\text { Head is } \\
\text { Male } \\
\text { (3) }\end{array}$ & $\begin{array}{l}\text { Head } \\
\text { Age } \\
(4)\end{array}$ & $\begin{array}{c}\text { Head has } \\
\text { at least } \\
\text { Sec. Educ. } \\
\text { (5) }\end{array}$ & $\begin{array}{c}\text { Hindu } \\
\text { HH } \\
(6)\end{array}$ & $\begin{array}{c}\text { Number } \\
\text { of } \\
\text { Females } \\
(7)\end{array}$ & $\begin{array}{c}\text { Number } \\
\text { of } \\
\text { Children } \\
\text { (8) }\end{array}$ \\
\hline ChildU & -0.004 & $-0.029 * * *$ & 0.001 & -0.123 & 0.002 & -0.005 & 0.010 & 0.005 \\
\hline XPost & $(0.00$ & $(0.007)$ & $(0.0$ & $(0.0$ & $(0.0$ & $(0$. & (0.009) & $(0.006$ \\
\hline $\begin{array}{l}\text { Pre-Ban Mean } \\
\text { of Dep. Variable }\end{array}$ & 0.529 & 6.268 & 0.914 & 44.611 & 0.127 & 0.783 & 3.045 & 3.203 \\
\hline Observations & 327,233 & 230,013 & 230,013 & 230 & 230,013 & 230,013 & 230,013 & 230,013 \\
\hline R-squared & 0.268 & 0.904 & 0.235 & 0.297 & 0.145 & 0.208 & 0.621 & 0.839 \\
\hline \multicolumn{9}{|c|}{$\begin{array}{l}* * * \mathrm{p}<0.01, * * \mathrm{p}<0.05, * \mathrm{p}<0.1 \text {. "ChildUnder } 14 \text { " is a dummy variable for whether there is at least } 1 \text { child } \\
\text { age } 10-13 \text { in the HH. Sample: HHs with at least one member ages } 6-17 \text {. Robust } \mathrm{SE} \text { reported. Controls: } \\
\text { gender and age of HH; urban status; counts of adult females, male children, female children, children under } \\
5 \text {, children ages 6-9; and the following fixed effects: family size, HH head's educ., relig., survey round, } \\
\text { survey quarter, state. For each age } 0-25 \text {, we include a separate variable which counts the no. household } \\
\text { members of that specific age. }\end{array}$} \\
\hline
\end{tabular}

TABLE A.6. Checking for Differential Trends using only Post-Ban Data

\begin{tabular}{lcc}
\hline \hline & \multicolumn{2}{c}{ Dependent Variable: Any Economic Activity } \\
\hline & Ages 6-9 & Ages 10-13 \\
& $(1)$ & -0.002 \\
\hline SibUnder14XPost1988 & -0.000 & $(0.003)$ \\
& $(0.001)$ & 106,937 \\
Observations & 98,591 & 106,937 \\
\hline Observations & 98,591 & 0.091 \\
R-squared & 0.020 & "
\end{tabular}


TABle A.7. Accounting for State Policies and Differential Effects of Economic Growth on Children

\begin{tabular}{|c|c|c|c|c|c|c|}
\hline & \multicolumn{6}{|c|}{ Dependent Variable: Any Economic Activity } \\
\hline & \multicolumn{2}{|c|}{$\begin{array}{c}\text { Includes State GDP } \\
\text { Index X Under14 }\end{array}$} & \multicolumn{2}{|c|}{$\begin{array}{c}\text { States with No Change } \\
\text { in Besley-Burgess Labor } \\
\text { Classifications (1983-1994) }\end{array}$} & \multicolumn{2}{|c|}{$\begin{array}{l}\text { States with Below } \\
\text { Median OB Intensity }\end{array}$} \\
\hline & Ages & Ages & Ages & Ages & Ages & Ages \\
\hline & $6-9$ & $10-13$ & $6-9$ & $10-13$ & $6-9$ & $10-13$ \\
\hline & (1) & (2) & (3) & (4) & (5) & (6) \\
\hline SibUnder14XPost & $\begin{array}{c}0.007 * * * \\
(0.002)\end{array}$ & $\begin{array}{l}0.009 * * \\
(0.004)\end{array}$ & $\begin{array}{c}0.005 * * * \\
(0.001)\end{array}$ & $\begin{array}{c}0.013 * * * \\
(0.003)\end{array}$ & $\begin{array}{l}0.003 * \\
(0.002)\end{array}$ & $\begin{array}{l}0.009 * * \\
(0.004)\end{array}$ \\
\hline $\begin{array}{l}\text { Pre-Ban Mean } \\
\text { of Dep. Variable }\end{array}$ & 0.016 & 0.114 & 0.011 & 0.093 & 0.009 & 0.083 \\
\hline Observations & 152,021 & 163,307 & 122,960 & 133,544 & 62,807 & 68,925 \\
\hline R-squared & 0.025 & 0.104 & 0.015 & 0.081 & 0.012 & 0.072 \\
\hline \multicolumn{7}{|c|}{$\begin{array}{l}\text { *** } \mathrm{p}<0.01, * * \mathrm{p}<0.05, * \mathrm{p}<0.1 \text { Cols }(1)-(2) \text { : State-level GDP (yearly) is calculated using state-level } \\
\text { census data as reported by IndiaStat (http://www.indiastat.com). The base year for the index is } 1983 . \\
\text { Cols (3)-(4): Sample excludes states that have experienced any labor regulation reform during the } \\
\text { period 1983-1994 as defined in Besley and Burgess (2004): Andhra Pradesh, Madhya Pradesh, and } \\
\text { Rajasthan. Cols (5)-(6): Intensity of Operation Blackboard figures taken from Chin (2005). } \\
\text { "SibUnder14"=dummy for whether the child has at least } 1 \text { sibling age 10-13. Controls for all } \\
\text { columns: gender, gender and age of HH; urban status; counts of adult females, male children, female } \\
\text { children, children under 5, children ages 6-9; and the following fixed effects: age, family size, HH } \\
\text { head's educ., relig., survey round, survey quarter, state. In addition to the listed controls, for each } \\
\text { age 0-25, we include a separate variable which counts the no. of households members of that } \\
\text { specific age. SEs are clustered by HH. Sample: all related to the HH head with at least one other } \\
\text { (related) HH member age 6-17. }\end{array}$} \\
\hline
\end{tabular}

